\title{
17
}

\section{CADERNOS BRASILEIROS DE MEDICINA}

\author{
JAN A DEZ - 2020 - Edição COVID-19 (Especial)
}

Editorial

Max Kopti Fakoury e Mario Barreto Corrêa Lima 05

Efeito da Exposição a Pacientes com Covid-19 no Desempenho Atencional em Funcionários do Hospital Universitário Gaffrée e Guinle

Effect of Exposure to Covid-19 Patients on Attention Performance in Workers at Gaffrée and Guinle University Hospital

Guilherme J. Schmidt, Eelco van Duinkerken, Carolina R. Mello, Paula R. Yuri Fukusawa, Denise H. Nicaretta, Sergio L. Schmidt.

Preditores de Sintomas de Ansiedade em Trabalhadores de Hospital Durante a Pandemia de COVID-19 Predictors of Anxiety Symptoms in Hospital Workers During Covid-19 Pandemic

Ana Lúcia Taboada Gjorup, Júlio Cesar Tolentino, Sergio L. Schmidt... 10

Análise dos Sintomas de Episódio Depressivo Maior na Pandemia de COVID em funcionários de hospital universitário do Rio de Janeiro

Symptoms analysis of a major depressive episode in the COVID pandemic of University Hospital Staff in Rio de Janeiro

André Casarsa Marques, Júlio Cesar Tolentino Júnior, Sergio Luis Schmidt..... 14

Há um Aumento na Prevalência da Dor Crônica Durante a Pandemia da COVID-19?

Is there an Increase in the Chronic Pain Prevalence During the COVID-19 Pandemic?

Vithória Vidotti Neves, Julio Cesar Tolentino Junior, Sergio L. Schmidt.....

Covid-19 Causa Alterações Atencionais a Longo Prazo

Covid-19 Leave Long-Term Attention Impairment

Aureo do Carmo Filho, Eelco van Duinkerken, Sergio Luis Schmidt.

Manifestações Otorrinolaringológicas na COVID-19

Ear, Nose and Throat manifestations at COVID-19

Amanda Dal Castel Ferreira da Silva, Michelly da Silva Nascimento de Farias, Alice Zopelar Almeida de Oliveira Pena, João Vitor Camargo de Abreu Silva, Manuella Caroline Dutra Frazão Alves, Alexia de Almeida Reis Rodrigues, Jorge da Cunba Barbosa Leite....

\section{Nota do Diretor}

João Marcelo Ramalbo Alves..... 34

Nota de Agradecimento do Corpo Editorial da Revista Cadernos Brasileiros de Medicina a Fundação de Apoio a Pesquisa, Ensino e Assistência à Escola de Medicina e Cirurgia do Rio de Janeiro e ao Hospital Universitário Gaffrée e Guinle, da Universidade Federal do Estado do Rio de Janeiro - FUNRIO 


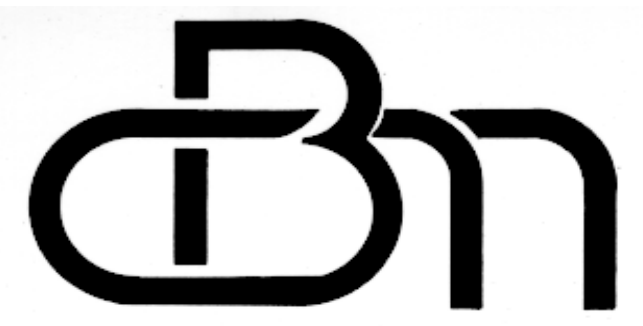

\section{CADERNOS BRASILEIROS DE MEDICIMA}

JAN A DEZ - 2020 - Edição COVID-19

\section{EDITOR CHEFE}

Mário Barreto Corrêa Lima

\section{EDITORES ADJUNTOS}

Aureo do Carmo Filho

Fernando Raphael de Almeida Ferry

Lucas Pereira Jorge de Medeiros

Marcelo Costa Velho Mendes de Azevedo

Maria Aparecida de Assis Patroclo

Max Kopti Fakoury

Max Rogério Freitas Ramos

\section{CONSELHO EDITORIAL}

Carlos Alberto Basílio de Oliveira (Anatomia Patológica)

Carlos Eduardo Brandão Mello (Gastroenterologia)

Luiz Eduardo da Motta Ferreira (Clínica Médica)

Maria Cecília da Fonseca Salgado (Reumatologia)

Maria Lúcia Elias Pires (Endocrinologia)

Omar da Rosa Santos (Nefrologia)

Omar Lupi da Rosa Santos (Dermatologia)

Paulo Henrique Murtinho Couto (Ortopedia)

Pietro Novellino (Cirurgia Geral)

Terezinha de Souza Agra Belmonte (Endocrinologia Infantil)

\section{ASSISTÊNCIA ADMINISTRATIVA}

Pedro Antonio André da Costa

PROJETO GRÁFICO E DIAGRAMAÇÃO

Apoio:

Luiz Eduardo da Cruz Veiga

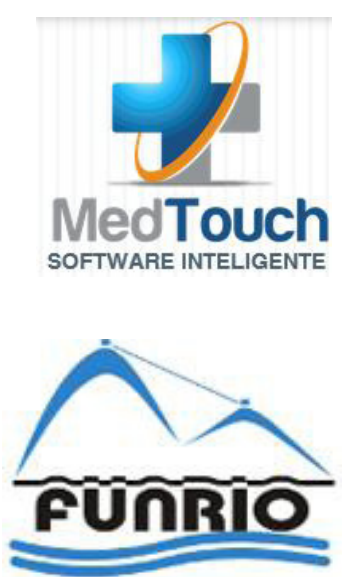




\section{INSTRUÇÕES AOS AUTORES}

Os Cadernos Brasileiros de Medicina (ISS 01034839/ISSN 1677-7840), é originalmente, produto do interesse científico na comunidade acadêmica do grupo docente e discente do Serviço do Professor Mário Barreto Corrêa Lima e dos demais serviços da Escola de Medicina e Cirurgia da Universidade Federal do Estado do Rio de Janeiro (UNIRIO).

A abertura da revista para os grupos de pesquisa de outros centros de reconhecimento é uma realidade a qual esta publicação vem atendendo nos últimos anos e que só vem a contribuir para o desenvolvimento da divulgação do saber médico.

A finalidade da revista é a publicação de trabalhos originais das diversas áreas da ciência e arte médicas. O conselho editorial, com plenos poderes de avaliação e julgamento, reconhecendo originalidade, relevância, metodologia e pertinência, arbitrará a decisão de aceitação dos artigos. O conteúdo do material publicado deve ser inédito no que se refere à publicação anterior em outro periódico, sendo, ainda de responsabilidade exclusiva dos autores os dados, afirmações e opiniões emitidas. As publicações dos Cadernos Brasileiros de Medicina versarão estruturadas a partir dos seguintes modelos:

Editorial: comentário em crítica produzido por editores da revista ou por escritor de reconhecida experiência no assunto em questão.

Artigos originais: artigos que apresentam ineditismo de resultado de pesquisa e sejam completos no que consta à reprodutibilidade por outros pesquisadores que se interessem pelo método descrito no artigo. Deverá observar, salvo desnecessário à regra, a estrutura formalizada de: introdução, método, resultados, discussão e conclusões.

Artigos de revisão: revisão da literatura científica disponível sobre determinado tema, respeitando, se pertinente, a estrutura formal anteriormente citada.

Artigos de atualização: contemplam atualização menos abrangente que o anterior - de evidências científicas definitivas para o bom exercício da ciência médica.

Breves comunicações: artigos sobre assuntos de importância premente para saúde pública ou que não se enquadre no rigor de artigos originais.

Relatos de casos: estudo descritivo de casos peculiares, em série ou isolados, que mereçam, pela representatividade científica e/ou riqueza de comentário, o interesse da comunidade profissional. Cartas: Opiniões e comentários sobre publicação da revista ou sobre temas de notório interesse da comunidade científica.

Resenhas: crítica em revisão de conteúdos publicados em livros, a fim de nortear o leitor da revista às características de tais publicações.

Formatação do escrito:

- envio de arquivo word, digitado em espaço duplo, com margens de $2,5 \mathrm{~cm}$ e com formato e tamanho de letra Arial, tipo 12.

- todas as páginas devem ser numeradas

- a primeira página deve conter: o título do trabalho - estreito e explicativo / nome completo dos autores com afiliação institucional / nome do departamento e instituição a qual o trabalho deve ser vinculado / nome, endereço, fax, endereço eletrônico (e-mail) do autor responsável e a quem deve ser encaminhada correspondência caso necessário.

- a segunda página deve constar de: resumo em português - onde se sugere a estrutura formalizada em apresentação de artigos originais -, e as palavras-chave - três descritores que indiquem a natureza do tema em questão (sugestão em Descritores em Ciências da Saúde - DECS: http:// decs.bvs.br)

- a terceira página constará de título e resumo em inglês (abstract) nos moldes do anterior associado às palavras-chave traduzidas em inglês (key words).

- a quarta página iniciará o corpo do texto:

* A formatação do texto deve respeitar o modelo ao qual se propõe (artigo original, carta, editorial, etc...).

* Abreviação de termos deverá ser precedida por escrito anterior em que se inclua o texto completo sucedido pela abreviação referente entre parênteses.

* Os nomes dos medicamentos devem respeitar a nomenclatura farmacológica.

* Tabelas devem ser enviadas em folha separada, numeradas com algarismos arábicos, na seqüência em que aparecem no texto, com legenda pertinente e auto-explicativa que deve se dispor na parte superior da tabela. Rodapés com informações relevantes sucintas são permitidos.

* Figuras e gráficos devem ser enviados em folha separada, na seqüência em que aparecem no texto, numerados com algarismos arábicos, com legenda 
pertinente e auto-explicativa que deve se dispor na parte superior da tabela. Rodapés com informações relevantes sucintas são permitidos.

* Tabelas, figuras e gráficos devem ser enviados em formato que permita a reprodução, e se necessário, devem ser mandadas individualmente. Observamos que deve ser sugerido com clareza pelos autores o local exato em que a inserção do anexado está indicada no texto.

* Referências bibliográficas devem ser numeradas consecutivamente em algarismos arábicos. Estas referências vão dizer sobre citações de autores sobrescritas e numeradas sequencialmente (ex: "são as hepatites"1) - que serão colocadas durante o corpo do texto, não cabendo, durante o texto, qualquer informação além sobre a referência. A apresentação das referências deve ser baseada no formato do grupo de vancouver (http://www. icmje.or) e os títulos dos periódicos deverão ser formatados de acordo com a National Library of Medicine da List of Journal Indexed Medicus. (http://nlmpubs.nlm.nih.gov/online/journals/ ljiweb.pdf) ou escritos por inteiro sem abreviação.

Exemplos do estilo de referências bibliográficas:

Artigos:

1. Vianna RR. A prevalência da demência de Alzheimer numa população de um bairro de idosos. Arq Bras Psiquiatr. 1997;18(3):111-5.

2. Teixeira A, Jonas J, Lira M, Oliveira G. A encefalopatia hepática e o vírus da hepatite c. Arch Eng Hepat. 2003;25(6):45-7.

3. Cardoso V, Jorge T, Motta F, Pereira C. Endo- cardite infecciosa e cirurgia de troca valvar. Jour Int Cardiol. 2001;77980:34.

Livros:

1. Rodrigues RH, Pereira J, Ferreira RL. A semiologia médica. $3^{\mathrm{a}}$ ed. Rio de Janeiro: Medica-rio editores; 2000.

Capítulo livro:

2. Lant FC, Cerejo PM, Castelo RB, Lage LL. Quedas em idosos. In: Barboza BZ, Azevedo VM, Salomão RC, editores. O idoso frágil. $1^{a}$ ed. São Paulo: Chateau e machara editora; 1992. p. 234-40.

- Agradecimentos são permitidos ao final do artigo.

Os trabalhos devem ser enviados por correio eletrônico ou por correio tradicional (via impressa com cópia em disquete ou CD-ROM).

Prof. Mário Barreto Corrêa Lima - Editor Chefe

Rua Figueiredo Magalhães, 286/309 -

Copacabana. Rio de Janeiro - RJ

CEP: 22031-010

E-mail: cadbrasmed@gmail.com

Endereço eletrônico: www.cadbrasmed.com.br

CBM. Cadernos Brasileiros de Medicina (on line) ISSN: $1677-7840$

ISS: 0103-4839 


\section{Editorial}

Max Kopti Fakoury ${ }^{1}$ e Mario Barreto Corrêa Lima ${ }^{2}$

Nossa Revista vem acompanhando as transformações científicas e de comunicação global, propondo neste ano o desafio de uma edição especial COVID, além da tradicional, com o tema que desafia o mundo e cada um de nós diante de tantas incertezas e com a gigantesca onda de desinformação que acompanha toda a "Pandemia". Sabemos que a medicina é "a Arte da incerteza e a Ciência da probabilidade" em um mundo com pensamentos e desejos imediatistas, que diante de uma nova doença, um vírus, que prejudica diversos sistemas orgânicos, com fisiopatologia não totalmente esclarecida, onde o combate com "antivirais" é incerto e historicamente o bloqueio de uma pandemia viral acontece com as medidas individuais de proteção( máscaras, distanciamento social, higiene nas mãos) até que uma vacina eficaz seja utilizada em larga escala, somos cobrados para entregarmos soluções milagrosas.

As vacinas em fases finais de teste, em tempo recorde com a tecnologia adequada, com a Inglaterra tomando a frente e vacinando em larga escala seu povo... Muitas perguntas ainda a serem respondidas, muita insegurança, muita desinformação... Mas trabalhamos com a ciência das probabilidades e nossa arte é incerta, mas já temos as probabilidades suficientes para o uso, mesmo com as incertezas.

A vacinação é o meio mais seguro e eficaz na prevenção de doenças, capaz de reduzir mortes. Um grupo de pesquisadores da Organização Mundial de Saúde publicou, recentemente, que na década de 1960, morriam 2,6 milhões de pessoas por anos no mundo antes da primeira vacina e depois de mais de $80 \%$ da população mundial ser imunizada, o número caiu para 95 mil no ano de 2017, a maioria de menores de cinco anos de idade, falando apenas de vacinação contra sarampo. Sobre o coronavírus, mais um pouco... estamos quase lá.

No começo do ano de 2020, não fazíamos ideia de como iria ser e o pior, se chegaríamos ao final. Perdemos muitos colegas, amigos e o número de mortes no mundo chega em dezembro a quase 2 milhões, sendo que no Brasil as mortes ultrapassaram 180 mil. Todos os profissionais de saúde se tornaram "grupo de risco" e "vetores", estando diante dos dois piores cenários que um ser humano pode passar: "ver alguém morrer sem poder ajudar" e "ver sua vida em risco".

Todos os profissionais de saúde fizeram valer o que há de mais nobre em suas ações e pensamentos, precisamos de respeito e não de desinformação. Olhamos hoje para o número de mortos e lamentamos muito todas as perdas, mas mais ainda os que poderiam ter sido evitadas com menos "desinformação".

A edição Especial COVID -19 foi pensada no modelo "short communications" para dar oportunidades a trabalhos iniciados e que não teriam em 2020 o tempo necessário para conclusão, pois sabemos que a maioria dos autores brasileiros da área da medicina não tem apoio financeiro e são sobrecarregados de atividades assistenciais e precisam um esforço impar para conseguir atender, pesquisar, "ir a bancada", escrever, estudar e cuidar de si; Esperamos que os leitores apreciem os trabalhos. Recebemos e publicamos também a nota do superintendente do Hospital Universitário Gaffreé e Guinle, sobre este momento.

Aproveitamos para agradecer e enaltecer todos os profissionais de saúde (de todos cantos do mundo), que mesmo cansados, continuam; mesmo com tantas perdas, continuam; mesmo adoecendo, continuam; mesmo com tanta desinformação, continuam; mesmo se sentindo culpados por serem "vetores" de alguém que amam, continuam!

Enceramos este editorial com o pedido insistente de que medidas individuais são fundamentais, o usar mascara é dizer que tem amor próprio e o distanciamento é dizer que ama o próximo; São as medidas mais eficazes, para que a ciência das probabilidades (os nossos cientistas) tenham o tempo necessário para apresentarem novas tecnologias em saúde e minimizem mais ainda o sofrimento.

${ }^{1}$ Professor Assistente de Clínica Médica da Escola de Medicina e Cirurgia da UNIRIO, Doutorando em Neurologia do PPGNEURO - UNIRIO. ${ }^{2}$ Professor Titular Emérito de Clínica Médica e de Doenças Infecciosas e Parasitárias da Escola de Medicina e Cirurgia da UNIRIO, Membro Titular da Academia Nacional de Medicina e Fundador e Editor Chefe dos Cadernos Brasileiros de Medicina. 


\title{
Efeito da Exposição a Pacientes com Covid-19 no Desempenho Atencional em Funcionários do Hospital Universitário Gaffrée e Guinle
}

\author{
Guilherme J. Schmidtt, Eelco van Duinkerken ${ }^{1,2}$, Carolina R. Mello ${ }^{3}$, Paula \\ R. Yuri Fukusawa ${ }^{4}$, Denise H. Nicaretta ${ }^{1}$, Sergio L. Schmidt ${ }^{1,4}$
}

\begin{abstract}
RESUMO
Objetivo: Investigar se a exposição a pacientes com COVID-19 poderia alterar o desempenho atencional de funcionários do Hospital Universitário Gaffrée \& Guinle. Método: Um teste computadorizado de atenção visual foi aplicado em 161 funcionários. Após os critérios de exclusão (uso de medicação psicotrópica), 124 funcionários foram divididos em 2 grupos: Baixa ou nenhuma exposição semanal e alta exposição semanal a pacientes com COVID-19. Resultados: O grupo com alta exposição apresentou piora significativa na atenção sustentada $(\mathrm{p}<5 \%)$. Conclusão: O pior desempenho na atenção sustentada pode refletir lapsos atencionais, o que poderia aumentar o risco de acidentes de trabalho no grupo de funcionários que trabalham diretamente com pacientes infectados pelo SARS-CoV-2.
\end{abstract}

Palavras-chave: atenção, variabilidade do tempo de reação, COVID-19.

Effect of Exposure to Covid-19 Patients on Attention Performance in Workers at Gaffrée and Guinle University Hospital

\begin{abstract}
Objective: To verify if attention performance was affected by exposure to COVID-19 patients in workers at Gaffree e Guinle University Hospital. Method: A computerized visual attention test was applied to 161 employees. After exclusion criteria (use of psychotropic medication), 124 workers were dichotomized into 2 groups: Low or no weekly exposure $(n=44)$ and high weekly exposure to patients with COVID-19 $(n=80)$. Results: The group with high exposure had poorer attention performance $(p<5 \%)$. Conclusion: The lower performance reflected attentional lapses, which may increase accident risk at work in the group of workers exposed to patients with COVID-19
\end{abstract}

Keywords: attention, variability of reaction time, COVID-19.

\footnotetext{
${ }^{1}$ Programa de Pós Graduação em Neurologia, Hospital Universitário Gaffrée e Guinle, Universidade Federal do Estado do Rio de Janeiro, Rio de Janeiro, RJ, Brasil. ${ }^{2}$ Departamento de Psicologia Médica, Amsterdam University Medical Centers, Vrije Universiteit, Amsterdam, Holanda. ${ }^{3}$ Departamento de Anestesiologia, Hospital Universitário Gaffrée e Guinle, Universidade Federal do Estado do Rio de Janeiro, Rio de Janeiro, RJ, Brasil. ${ }^{4}$ Gerência de Ensino e Pesquisa, EBSERH, Hospital Universitário Gaffrée e Guinle, Universidade Federal do Estado do Rio de Janeiro, Rio de Janeiro, RJ, Brasil.

\author{
Correspondência \\ Guilherme J. Schmidt \\ Rua Mariz e Barros, 775 \\ 20270-901 - Maracanã/RJ \\ Brasil \\ E-mail: guilhermejschmidt@gmail. \\ com
}




\section{INTRODUCTION}

During the current COVID-19 pandemic, workers in close contact with COVID-19 patients are particularly vulnerable to psychological stress ${ }^{1}$. Previous studies have suggested that individual brain network under acute stress controls the cognitive consequences of threat ${ }^{2}$. Stress responses via catecholaminergic pathways may have selective effects on brain regions that include the temporoparietal and cingulate cortices, amygdala, thalamus, striatum, and the brainstem. Changes in these regions are followed by changes in the executive control network in the prefrontal cortex. These regions are associated with attention performance ${ }^{3}$. Accordingly, Schmidt et al. ${ }^{4}$ reported deficits in attention performance under stress. Therefore, attentional impairments would be expected in workers in close contact with COVID-19 patients. However, as far as we know, this issue has not been studied during the current pandemic.

Attentional performance can be measured using computerized Go/No-go reaction-time paradigms 5 . In Brazil, the Computerized Visual Attention Test (CVAT) is validated for clinical use $^{6}$. Schmidt et al. ${ }^{7}$, using positron emission tomography, showed that the CVAT activates the prefrontal cortex. Considering the possible effect of stress on the prefrontal cortex, attention deficits would be expected in workers in contact with COVID-19 patients.

Here we aimed to investigate if hospital employees with high exposure to COVID-19 patients showed attentional impairments as compared to those with low exposure.

\section{MATERIALS AND METHODS}

This study was approved by the Ethics Committee of the Gaffrée and Guinle University Hospital (Plataforma Brasil CAAE:30547720.3.0000.0008) and was in accordance with the Declaration of Helsinki for medical research involving human subjects. Written informed consent was obtained from all the participants.

\section{Participants}

All participants were workers at the University Hospital. Age ranged between 22 to 66 years. Exclusion criteria: Diabetes mellitus; current or previous neurologic disease; and use of drugs that can impair attention, like hypnotic sedative drugs, tricyclic antidepressants, anti-psychotics, muscle relaxants, antihistamines, and glucocorticoids.

Groups were divided accordingly to COVID-19 weekly hours of exposure $(<24$ hours, low-exposure; $\geq 24$ hours, high-exposure).

\section{CVAT}

Participants were seated in front of a laptop computer to allow the dominant hand to be placed over the keyboard. Before each task, the examiner instructed the subject to press the spacebar as fast as possible each time a specific visual target stimulus was displayed on the monitor. The test started with instructions and a practice session. The full version of the CVAT lasts 15 minutes $^{5,8,9,10}$. However, as the present investigation was designed to assess a large number of participants in a short time period, we administered an abridge form of the CVAT (90 seconds). This form had previously been used in elderly ${ }^{11,12}$. It includes 90 trials (80\% targets, $20 \%$ non-target) with an interstimulus interval of 1 second. The types of measures included omission errors, commission errors, reaction time, and intraindividual variability of reaction times. Participants with less than $50 \%$ of correct responses on CVAT were excluded. Response times lower than 150 milliseconds were excluded.

\section{STATISTICAL ANALYSIS}

A MANCOVA was performed including all the CVAT variables as dependent variables and exposure to COVID-19 as independent variable (low vs. high exposure). Age and sex were cofactors. In case of a significant overall MANCOVA, post-hoc ANCOVAs of each dependent variable was checked for statistical significance.Significance was set at $\mathrm{p}<5 \%$. Analyses were performed using SPSS 25.

\section{RESULTS}

The continuous visual attention test (CVAT) was administrated in 161 hospital workers. After applying the exclusion criteria, 124 workers were included in this study. There was not significant group difference in mean ages (high-exposure, $n=80$, Mean $=42.71$ years, Standard deviation $=10.02$ years; low-exposure, $n=44$, Mean= 39.61 years, Standard deviation $=10.68$ years). 
The percentage of females did not differ (High- exposure $=66 \%$; Low-exposure $=65 \%$ ).

Analysis of the raw data showed that the high-exposure group made more errors, had slower response time, and higher variability of reaction time (Table1).

Table 1. Raw scores (CVAT)

\begin{tabular}{lcc}
\hline & Low Exposure $(\mathbf{n}=44)$ & High Exposure $(\mathbf{n}=\mathbf{8 0})$ \\
\hline CVAT Variables & $1.77 \pm 4.67$ & $3.54 \pm 7.40$ \\
Omission Errors & $14.77 \pm 13.55$ & $18.61 \pm 13.44$ \\
Commission Errors & $370.73 \pm 36.05$ & $388.26 \pm 47.28$ \\
Reaction Time (ms) & $65.32 \pm 17.43$ & $81.20 \pm 35.25$ \\
Variability of Reaction Times $(\mathrm{ms}) *$ & $1.60(0-10)$ & $1.29(0-21)$ \\
\hline Abbreviation: CVAT $=$ Computerized Visual Attention Test. CVAT variables are represented by mean \pm standard error of \\
the mean. ${ }^{*}$ represents group differences that reached significant level $<5 \%$.
\end{tabular}

The overall MANCOVA, after correction for age and sex, was statistically significant $(F=2.72, d f=4 / 117, P=0.03)$. Sex and age also reached significance. Further analysis using post-hoc ANCOVAs showed that the mean intraindividual variability of reaction times of the correct responses was significantly higher in the high exposure group as compared to their counterparts with low exposure to COVID-19 patients $(\mathrm{F}=6.68, \mathrm{df}=1 / 120, \mathrm{P}=0.01)$. Conversely, group differences in reaction time, omission and commission errors did not reach a significant difference.

\section{DISCUSSION}

Hospital employees with a close contact with COVID-19 patients performed worse in the CVAT, particularly in the variability of reaction time. This variable is associated with sustained-attention ${ }^{8}$. Schmidt et al. $^{4}$ have described that sustained-attention subdomain can be affected by a stressful situation. One explanation for this phenomenon could be an increased stimulation for the adrenal production of glucocorticoids in stressful situations by the hypothalamic-pituitary axis $^{14,15}$. These glucocorticoids bind into receptors located in the prefrontal cortex ${ }^{14}$, a cerebral region that plays a central role in sustained attention control, impairing attentional functioning.

The worse performance in the sustained attention subdomain may reflect lapses in attention $^{16}$. Thus, the group with a higher COVID-19 patient exposition may be at a higher risk of work accidents, including SARS-CoV-2 contamination.

Limitations of this study included unequal sample sizes and the possible influence of other confounding variables, such as, sleep quality and previous COVID-19 infection. As age and sex affected CVAT, further investigation should address this question using samples paired by age and sex including sleep quality and previous COVID-19 infection as covariates. Another limitation is the duration of the test. Although the test allowed 36 to 72 measurements of correct reaction times per participant, the short duration of the CVAT abridged version ( 90 seconds) may cause a reduction in the total number of errors, as compared to the 15-min version of the test. Thus, it would be of interest to assess performance with the longer CVAT form.

In conclusion, the present data support that hospital workers who are in close contact with COVID-19 patients show lapses of attention. 


\section{REFERÊNCIAS}

1. Lai J, Ma S, Wang Y, Cai Z, Hu J, Wei N, et al. Factors Associated With Mental Health Outcomes Among Health Care Workers Exposed to Coronavirus Disease 2019. JAMA Netw open. 2020;3(3):e203976.

2. Kohn N, Hermans EJ, Fernández G. Cognitive benefit and cost of acute stress is differentially modulated by individual brain state. Soc Cogn Affect Neurosci. 2017;12(7):1179-87.

3. Petersen SE, Posner MI. The Attention System of the Human Brain: 20 Years After. Annu Rev Neurosci. 2012;35(1):73-89.

4. Schmidt SL, Schmidt GJ, Padilla CS, Simões EN, Tolentino JC, Barroso PR, et al. Decrease in Attentional Performance After Repeated Bouts of High Intensity Exercise in Association-Football Referees and Assistant Referees. Front Psychol. 2019;10:1-15.

5. Schmidt G, Alvarenga R, Manhães A, Schmidt S. Attentional performance may help to identify duloxetine responders in chronic pain fibromyalgia patients. Eur J Pain. 2017;21(6):977-86.6.

6. Conselho Federal de Psicologia [Internet]. CFP. [cited 2020 Oct 19]. Available from https://site.cfp. org.br/

7. Schmidt SL, Correa PL, Tolentino JC, Manhães AC, Felix RM, Azevedo JC, et al. Value of combining activated brain FDG-PET and cardiac MIBG for the differential diagnosis of dementia: Differentiation of dementia with lewy bodies and alzheimer disease when the diagnoses based on clinical and neuroimaging criteria are difficult. Clin Nucl Med. 2008;33(6):398-401.

8. Schmidt SL, Simões E do N, Novais Carvalho AL. Association Between Auditory and Visual Continuous Performance Tests in Students With ADHD.
J Atten Disord. 2016;23(6):635-40.

9. Simões EN, Carvalho ALN, Schmidt SL. What does handedness reveal about ADHD? An analysis based on CPT performance. Res Dev Disabil. 2017;65:4656.

10. Simões EN, Padilla CS, Bezerra MS, Schmidt SL. Analysis of attention subdomains in obstructive sleep apnea patients. Front Psychiatry. 2018;9:435.

11. Schmidt G, Boechat Y, Schmidt S. Distinguishing early stage Alzheimer's disease from mild cognitive impairment using a quick and cultural free computerized attention test. J Neurol Sci. 2017;381:777-8.

12. Schmidt $G$, Boechat $Y$, van Duinkerken E, Schmidt J, Moireira T, Nicaretta D, et al. Detection of cognitive dysfunction in elderly with a low educational level using a reaction-time attention task. J Alzheimers Dis. Forthcoming 2020. DOI 10.3233/JAD-200881.

13. Schmidt SL, Manhães AC. Manual do Teste Computadorizado De Atenção: Normas, Fidedignidade e Validade Visual [Guidebook of the Continuous Visual Attention Test: Norms, Reliability, and Validity]. Rio de Janeiro: Cognitive Neuropsychology; 2019.

14. Herman JP, McKlveen JM, Solomon MB, Carvalho-Netto E, Myers B. Neural regulation of the stress response: glucocorticoid feedback mechanisms. Brazilian J Med Biol Res. 2012;45:292-8.

15. Nibbeling N, Oudejans RRD, Ubink EM, Daanen HAM. The effects of anxiety and exercise-induced fatigue on shooting accuracy and cognitive performance in infantry soldiers. Ergonomics. 2014;57(9):1366-79.

16. Egeland J, Kovalik-Gran I. Measuring several aspects of attention in one test: The factor structure of conners's continuous performance test. J Atten Disord. 2010;13(4):339-46. 


\title{
Preditores de Sintomas de Ansiedade em Trabalhadores de Hospital Durante a Pandemia de COVID-19
}

\author{
Ana Lúcia Taboada Gjorup ${ }^{1}$, Júlio Cesar Tolentino ${ }^{1}$, Sergio L. Schmidtt ${ }^{2,3}$
}

\section{RESUMO}

Introdução: Em um mesmo individuo, os sintomas de ansiedade (SA) tendem a diminuir com o tempo. Desta forma, o número de sujeitos que mantem SA normalmente diminui ao final do $6^{\circ}$ mês. Considerando o alto nível de estresse causado pela pandemia, pode-se especular uma maior prevalência na persistência dos AS por seis meses quando comparada com aquela comumente observada em condições normais. Isto deve ser particularmente acentuado em trabalhadores de hospitais envolvidos com o tratamento da COVID-19. Objetivos: 1) Calcular a prevalência da manutenção de SA por mais de 6 meses (iniciando antes da pandemia). 2) Identificar o melhor preditor para a persistência dos SA. Métodos: Estudo realizado no Hospital Universitário Gaffrée e Guinle (Brasil). Sexo, idade, nível educacional, afiliação religiosa, bem estar espiritual e SA foram obtidos através de questionários autoaplicáveis. Critérios de exclusão: uso de medicações ansiolíticas, idade $>60$ anos. Resultados: A prevalência dos SA foi de 61.8\% (n=86/139). A regressão logística mostrou que a o bemestar espiritual foi o melhor preditor dos SA. Indivíduos com baixo bem-estar espiritual apresentaram tendência para manterem os SA. Conclusões: 1) Grande parte dos trabalhadores do hospital manteve SA durante a pandemia. 2) O bem estar espiritual foi o melhor preditor da persistência dos SA

Palavras-chave: ansiedade, espiritualidade, pandemia, trabalhadores da saúde.

\section{Predictors of Anxiety Symptoms in Hospital Workers During Covid-19 Pandemic}

\begin{abstract}
Introduction: The number of subjects that maintains anxiety symptoms (AS) usually decreases at the end of the 6th month. During COVID-19 outbreak, the persistence of AS has not been systematically investigated. In epidemic outbreaks, hospital workers (HW) are subjected to stressful situations. Objectives: 1) To calculate the prevalence of AS in HW that had persisted for six-months (starting before pandemic). 2) To identify the most reliable predictor for persisted AS (2nd). Methods: The study was conducted at Gaffrée-Guinle University Hospital (Brazil). Sex, age, education, religious affiliation, SpiritualWell-Being (SWB), and AS were obtained through a self-reported questionnaire. Exclusion criteria: use of anxiolytic medications, age $>60$ years. Results: The prevalence of anxiety symptoms was $61.8 \%(n=86 / 139)$. The logistic regression
\end{abstract}

\footnotetext{
${ }^{1}$ Departamento de Medicina Interna, Hospital Universitário Gaffrée e Guinle, Universidade Federal do Estado do Rio de Janeiro, RJ, Brasil. ${ }^{2}$ Programa de Pósgraduação de Neurologia, Departamento de Neurologia, Hospital Universitário Gaffrée e Guinle, Universidade Federal do estado do Rio de Janeiro, RJ, Brasil. ${ }^{3}$ Gerência de Ensino e Pesquisa, Hospital Universitário Gaffrée e Guinle, Universidade Federal do estado do Rio de Janeiro, EBSERH, Rio de Janeiro, RJ, Ministério da Educação e Cultura, Brasil.

\author{
Correspondência \\ Ana Lúcia Taboada Gjorup \\ Rua Mariz e Barros, 775 \\ 20270-901 - Maracanã/RJ \\ Brasil \\ E-mail: ana.gjorup@unirio.br
}


mode showed that SWB was the most reliable predictor of AS. Conclusions: 1 ) A high proportion of HW maintained AS during pandemic. 2) Low SWB was associated with persistence of AS for six months.

Keywords: anxiety, predictors, spirituality, pandemic, healthcare workers. 


\section{INTRODUCTION}

Anxiety symptoms (AS) are commonly found worldwide ${ }^{1-3}$, and were seen to be highly prevalent in healthcare workers in the past viral outbreaks ${ }^{4}$. In 6 months, it would be expected that the number of subjects that maintain AS decreases at the end of the $6^{\text {th }}$ month. In non-epidemic situations, reliable predictors of AS have been described, such as, sex, educational level, and age $^{1,2}$. In particular, AS have been reported during the current COVID-19 pandemic ${ }^{5}$. However, the predictors of persistent AS are poorly studied in the current outbreak.

It would be possible that besides the traditional predictors, others could influence the AS during the new coronavirus outbreak. In this sense, previous studies have reported a protective effect of Spiritual Well Being (SWB) on $\mathrm{AS}^{6,7}$. It is relevant to mention that, the concept of spirituality differs from religiosity or religious affiliation ${ }^{8,9}$. To our knowledge, spirituality has not been studied in the COVID-19 outbreak among hospital workers. The present study aimed to investigate the proportion of hospital workers that have shown AS for 6 months starting before the current pandemic (First Objective). We also investigated which independent variables were reliable predictors for the persistence of AS during the 6th month period (Second Objective). We hypothesized that SWB would be an important predictor for the persistence of the AS during the current pandemic.

\section{METHODS}

This study was conducted face to face at Gaffree Guinle University Hospital in the city of Rio de Janeiro, Brazil, from $12^{\text {th }}$ May to 10th July 2020. The exclusion criteria were: age $>60$ years, and use of anxiolytic medication. Written formal consent was obtained from each participant (ethical approval: CAAE 30547720.3.0000.00080). They filled a self-reported questionnaire for AS. We also collected information about the predictors, as follows: SWB, age, sex, educational level, and religious affiliation.

Spiritual Well-Being was assessed using a validated scale entitled "The Functional Assessment of Chronic Illness Therapy-Spiritual Well-being (FACIT-Sp 12)"10. To assess religious affiliation, the participants answered a question asking if they were practicing any religion at the moment. Educational level was categorized in secondary (undergraduate) and tertiary (graduate/postgraduate). The anxiety symptom were measured in an all-or-none fashion based on the participant's answer if in the past six months he (or she) felt overly concerned, restless, and/or anxious about various problems in everyday life.

\section{STATISTICAL ANALYSIS}

Binominal logistic regression was performed to predict whether the participants could be correctly classified according to AS from Sex, Age, Educational Level, Religion Affiliation, and Spiritual Well-Being. The Nagelkerke R square value was calculated to estimate the explained variation in the dependent variable. The Wald test was used to determine statistical significance for each one of the predictors.

SPSS Statistics for Windows, version 24.0 (SPSS Inc., Chicago, IL) was used for analysis, and the significance level was set at $\mathrm{p}<0.5$.

\section{RESULTS}

From the initial random sample of 161 hospital employees, 139 workers were eligible to be included in this study $(84.9 \%$ healthcare workers $n=118)$. The age ranged from 22 to 60 years $(M=41.3, S D=9.9), 68.3 \%(n=95)$ females.

The prevalence of anxiety symptoms was $61.8 \%$ $(n=86)$. The logistic regression model was statistically significant $\left[\chi^{2}(27.62), \mathrm{p}<0.01\right]$ using as predictors age, sex, education level, religious affiliation and FACIT-Sp score. The model explained 25\% (Nagelkerke R2) of the variance and correctly classified $69.8 \%$ of cases. The Wald test indicated that only the FACIT-Sp score added significantly to the model (Wald=12.342, df=1, $\mathrm{p}<0.001, \operatorname{Exp}(B)=0.894,95 \%$ CI: 0.839-0.951).

\section{DISCUSSION}

Our results indicate that a high proportion of hospital workers maintained the AS that had started before the pandemic. SWB was the most reliable predictor of AS. Higher SWB was found to protect against to AS.

We found a $61.8 \%$ prevalence of persistent AS. Accordingly, previous investigations have reported a significant elevation of $\mathrm{CO}$ VID-19 related anxiety as compared to the global prevalence of AS out of epidemic outbreaks ${ }^{11}$. 
Our result may reflect that hospital workers are particularly vulnerable to AS during COVID-19. As our sample included healthcare and non-healthcare workers, future investigations should be conducted to evaluate the predictors of AS in both subsamples.

SWB was found to be the best predictor of the persisted AS. Spirituality, independent of religious practice, has been directly linked to

\section{REFERÊNCIAS}

1. Baxter AJ et al. Global prevalence of anxiety disorders: a systematic review and meta-regression. Psychol Med Cambridge,. 2013;43(5):897-910.

2. Bandelow B, Michaelis S. Epidemiology of anxiety disorders in the 21st century. Dialogues Clin Neurosci [Paris], [Internet]. 2015 [cited 2020 Sep 6];17(3):327-35. Available from: www.dialogues-cns. org

3. Remes $\mathrm{O}$ et al. A systematic review of reviews on the prevalence of anxiety disorders in adult populations. Brain Behav [s 1],. 2016;6(7):e00497.

4. Serrano-Ripoll MJ et al. Impact of viral epidemic outbreaks on mental health of healthcare workers: a rapid systematic review and meta-analysis. J Affect Disord [Internet]. 2020 [cited 2020 Oct 22];277:34757. Available from: https://doi.org/10.1016/j. jad.2020.08.034

5. Cai Q et al. The mental health of frontline and non-frontline medical workers during the coronavirus disease 2019 (COVID-19) outbreak in China : a case-control study. J Affect Disord [s 1], [Internet]. 2020;275(July):210-5. Available from: https://doi. org/10.1016/j.jad.2020.06.031

6. Johnson KS, Tulsky JA, Hays JC, Arnold RM, Olsen MK, Lindquist JH, et al. Which Domains of Spirituality are Associated with Anxiety and Depression in Patients with Advanced Illness? J Gen Intern Med. 2011;26(7):751-9. psychological resilience ${ }^{12,13}$. This could explain the protection of SWB on the AS.

\section{CONCLUSIONS}

A high proportion of hospital workers maintained their AS during pandemic $\left(1^{\text {st }}\right.$ objective). SWB was found to be highly associated with the persistence of AS $\left(2^{\text {nd }}\right)$. A lower SWB indicates a higher probability of keeping AS for more than 6 months.

7. Steiner LM, Zaske S, Durand S, Molloy M, Arteta R. Spiritual Factors Predict State and Trait Anxiety. J Reli Heal. 2017;56:1937-55.

8. Vitorino LM et al. The association between spirituality and religiousness and mental health. Sci Reports, [s 1],. 2018;8(1):1-9.

9. Koenig HG. Review Article Religion, Spirituality, and Health: The Research and Clinical Implications. 2012;2012:33.

10. Pereira F, Santos C. Adaptação cultural da Functional Assessment for Chronic Illness Therapy-spriritual well being (FACIT-Sp): estudo de validação em doentes oncológicos na fase final de vida. Cad Saúde, Rio Janeiro,. 2011;4(2):37-45.

11. Solomou I, Constantinidou F. Prevalence and predictors of anxiety and depression symptoms during the COVID-19 pandemic and compliance with precautionary measures : age and sex matter. Int J Environ Res Public Heal [s 1], [Internet]. 2020 [cited 2020 Oct 8];17(14):1-19. Available from: www.mdpi.com/ journal/ijerph

12. Mcclintock $\mathrm{CH}$ et al. How spirituality may mitigate against stress and related mental disorders: a review and preliminary neurobiological evidence. Curr Behav Neurosci Reports, [s 1],. 2019;6(4):253-62.

13. Tuck I, Anderson L. Forgiveness, flourishing, and resilience : the influences of expressions of spirituality on mental health recovery. Issues Ment Heal Nursing, [s 1],. 2014;35(4):277-82. 


\title{
Análise dos Sintomas de Episódio Depressivo Maior na Pandemia de COVID em funcionários de hospital universitário do Rio de Janeiro
}

André Casarsa Marques ${ }^{1}$, Júlio Cesar Tolentino Júnior ${ }^{1}$, Sergio Luis Schmidt ${ }^{1,2,3}$

\begin{abstract}
RESUMO
O objetivo da presente avaliação foi verificar a prevalência dos sintomas somáticos e afetivos em indivíduos rastreados para depressão maior (EDM) durante a pandemia da COVID-19. O estudo foi conduzido em funcionários do Hospital Universitário Gaffree e Guinle, Rio de Janeiro, Brasil. Os participantes foram submetidos ao rastreio de depressão pelo PHQ9. Pela resposta aos itens deste questionário foi possível diferenciar os sintomas depressivos entre somáticos e afetivos. O rastreio para EDM foi positivo em 46 participantes (29,1\%). O estudo em questão demonstra alta prevalência de sintomas de depressão em profissionais de saúde durante a COVID-19. Sintomas somáticos associados foram mais frequentes, o que chama atenção para o maior risco cardiovascular nesta amostra.
\end{abstract}

Palavras-chave: depressão, pandemia, COVID-19.

Symptoms analysis of a major depressive episode in the COVID pandemic of University Hospital Staff in Rio de Janeiro

\begin{abstract}
In order to verify the prevalence of somatic and affective symptoms in individuals screened for major depression (MDE) during the COVID-19 pandemic. The study was conducted on employees of the University Hospital Gaffree e Guinle, Rio de Janeiro, Brazil. Participants underwent screening for depression by PHQ9. By answering the items in the questionnaire, it was possible to differentiate depressive symptoms of depression in health professionals during COVID-19. Screening for EDM was positive in 46 participants $(29.1 \%)$. The study in question shows a high prevalence of symptoms of depression in health professionals during COVID-19. Associated somatic symptoms were more common which calls attention to the higher cardiovascular risk in this sample.

Keywords: depression, pandemic, COVID-19.
\end{abstract}

\footnotetext{
${ }^{1}$ Departmento de Medicina Interna, Hospital Universitário Gaffrée e Guinle, Universidade Federal do Estado do Rio de Janeiro, Rio de Janeiro, RJ, Brasil. ${ }^{2}$ Programa de Pós-Graduação em Neurologia, Departmento de Neurologia, Hospital Universitário Gaffrée e Guinle, Universidade Federal do Estado do Rio de Janeiro, Rio de Janeiro, RJ, Brasil. ${ }^{3}$ Gerência de Ensino e Pesquisa, Hospital Universitário Gaffrée and Guinle, Universidade Federal do Estado do Rio de Janeiro, EBSERH, Rio de Janeiro, RJ, Ministério da Educação e Cultura, Brasil.
}

Correspondência André Casarsa Marques Rua Mariz e Barros, 775 20270-901 - Maracanã/RJ Brasil

E-mail: andrecasarsamarques@ gmail.com 


\section{INTRODUCTION}

Depression is a common clinical syndrome with a chronic and recurrent course which has an estimated lifetime prevalence of $10 \%$ of the population1. In situations like the COVID-19 pandemic, there is a significant increase in the prevalence of depression symptoms, particularly in health workers ${ }^{2,3}$.

The diagnosis of depression is currently based on the classification of the Diagnostic and Statistical Manual 5 (DSM-5) ${ }^{4}$. The Patient Health Questionnaire-9 (PHQ-9) ${ }^{5}$ can be used to assess and screen the symptoms of such a mental disorder.

A recent PHQ-9 factorial analysis revealed that depressive symptoms can be grouped into two dimensions (somatic and affective) ${ }^{6}$.

According to Tolentino and Schmidt, the predominance of somatic symptoms characterizes moderate depression?

The present study aimed to investigate the prevalence of depressive somatic and affective symptoms during the COVID-19 pandemic among hospital workers.

\section{MATERIALS AND METHODS}

A cross-sectional study was carried out among healthcare workers at the Gaffrée Guinle University Hospital in the Rio de Janeiro city, Brazil, from May 12 May and July 10, 2020.

The initial sample consisted of 158 individuals.

Written formal consent was obtained from each participant (ethical approval: CAAE 30547720.3.0000.00080). They filled a self-reported questionnaire that consisted of sociodemographic items and depression assessment.

The symptoms of depression were assessed using the PHQ-9 Inventory, which had its validity tested at different levels of health care and is a relatively fast application tool, containing nine questions. Somatic symptoms are as follows: difficulty sleeping, changes in appetite, worsening concentration, fatigue and psychomotor disorders. Non-somatic or affective ones are negative feelings of lesser value, anhedonia and suicide.

The screening was considered positive in the presence of five or more symptoms, provided that at least one is depressed mood or anhedonia, and that each symptom corresponds to answer 2 or 3 ("a week or more" and "almost every day", res- pectively), with the exception of the suicide symptom, for which any value from 1 to 3 " "less than a week", "a week or more" and "almost every day", respectively) is acceptable.

For the analysis of the symptoms of depression, each item in the PQH-9 was scored as all (1) or nothing (0). Zero was considered to be the person who did not have the symptom or who had less than half the days in 2 weeks. Score 1 was considered for those who had symptoms for more than half the days or every day in the period of 2 weeks. As there are 5 somatic questions and 3 affective questions, the average scores of the items were measured to define somatic or affective depression. We consider depression to be predominantly somatic when the average scores of somatic items were higher than affective ones, and vice versa for predominantly affective depression.

\section{STATISTICAL ANALYSIS}

Quantitative variables are reported as absolute and relative frequencies, means, and standard deviations. SPSS Statistics for Windows, version 24.0 (SPSS Inc., Chicago, IL) was used for analysis.

\section{RESULTS}

Of the 158 patients evaluated, age ranged between 25 and 61 years (mean $=39.82$; standard deviation 10.03). Most of the participants (34 individuals, $73 \%$ ) were female. Screening for EDM was positive in 46 participants $(29.1 \%)$.

Somatic symptoms predominated in individuals with positive screening for $\operatorname{EDM}(\mathrm{n}=34$, $73 \%)$. Twelve individuals $(27 \%)$ had a predominance of affective symptoms. Thirty-nine participants $(84 \%)$ had sadness, a symptom that scores as both somatic and affective.

Among the somatic symptoms, 41 (89.1\%) of the individuals reported insomnia, $40(86 \%)$ fatigue, $32(69 \%)$ with altered appetite, $32(69 \%)$ with difficulty concentrating and $21(45 \%)$ with psychomotor agitation or delay. Regarding affective symptoms, 39 participants (84\%) had anhedonia, $28(60 \%)$ feelings of low self-esteem and 10 (21\%) suicide.

\section{DISCUSSION}

From the studies accomplished, a high prevalence of major depressive episode in the pandemic was detected, in comparison to the 
available literature.

From the studies accomplished, a high prevalence of major depressive episode in the pandemic was detected, in comparison to the available literature.

In the studied group, a high number of individuals with sleep disorders stands out. The relationship between poor sleep quality and depression is well defined. There was a high prevalence of anhedonia which is peculiar to MDE during the COVID 19 pandemic in this sample.

The difference among the symptoms of depression makes it possible to assess the severity of depression and allows establishing

\section{REFERÊNCIAS}

1. Kessing LV. Epidemiology of subtypes of depression. Acta Psychiatr Scand. (2007) 115:85-9. doi: 10.1111/j.1600-0447.2007.00966.x.

2. Lai J, Ma S, Wang Y, Cai Z, Hu J, Wei N, et al. Factors associated with mental health outcomes among health care workers exposed to coronavirus disease. JAMA.2019;3(3):e203976.https:// doi.org/10. 1001/jamanetworkopen.2020.3976.

3. Liu S, Yang L, Zhang C, Xiang YT, Liu Z, Hu $\mathrm{S}$, et al. Online mental health services in China during the COVID-19 outbreak. Lancet Psychiatry. 2020;7(4):e17-8. https://doi.org/10.1016/ S2215-0366(20)30077-8.

4. Manual diagnóstico e estatístico de transtornos mentais: DSM-5/[American Psychiatric Association ; tradução: Maria Inês Corrêa Nascimento ... a relationship to cardiovascular risk, since the predominantly somatic MDE is associated with a higher prevalence of autonomic disfunction. The occurrence of moderate depression in greater quantity in the studied population suggests a higher cardiovascular risk.

Among the study's limitations, there is a small sample and a high number of female individuals.

\section{CONCLUSION}

The study in question shows a high prevalence of symptoms of depression in health professionals during COVID-19. Associated somatic symptoms were more frequent.

et al.] ; revisão técnica: Aristides Volpato Cordioli ... [et al.]. - 5. ed.

5. Kroenke K, Spitzer RL, Williams JB. The PHQ9: validity of a brief depression severity measure. J Gen Intern Med 2001; 16:606-13.

6. Boothroyd L, Dagnan D, Muncer S, PHQ9: One factor or two?, Psychiatry Research (2018), doi: https://doi.org/10.1016/j. psychres.2018.12.048.

7. Tolentino JC, Schmidt SL. DSM-5 Criteria and Depression Severity: Implications for Clinical Practice. Front Psychiatry. (2018);9:450. doi:10.3389/fpsyt.2018.00450.

8. Tolentino JC, Schmidt SL. Association between depression severity and cardiac autonomic modulation. J Psychosom Res. (2016) 85:9-11. doi: 10.1016/j.jpsychores.2016.03.125. 


\title{
Há um Aumento na Prevalência da Dor Crônica Durante a Pandemia da COVID-19?
}

\author{
Vithória Vidotti Neves ${ }^{1}$, Julio Cesar Tolentino Junior ${ }^{1}$, Sergio L. Schmidt ${ }^{2,3}$
}

\section{RESUMO}

The COVID-19 outbreak could lead to worsening chronic pain (CP) and even the development of new pain cases. The objective of this study was to make a mini-review CP prevalence during the pandemic. Peer-reviewed scientific articles, including reviews and case reports, were researched. In the following bases: MEDLINE/Pubmed, EMBASE e Google Academic. Gray literature was also searched, including: Google Academic, bioRxiv and medRxiv. Search period: from February to October 2020, using the search terms ("chronic pain" AND "coronavirus" OR "COVID-19"). In one survey conducted by the Spanish Pain Society, 57\% (151/264) of participants reported worsening $\mathrm{CP}$ during the pandemic. However, they did not investigate new cases of pain during this period. To our knowledge, this is the first review in on CP prevalence during the COVID-19 outbreak. Although an increase in CP prevalence would be expected, we have not found any study on this subject.

Palavras-chave: dor crônica, COVID-19, prevalência.

Is there an Increase in the Chronic Pain Prevalence During the COVID-19 Pandemic?

\section{ABSTRACT}

The COVID-19 outbreak could lead to worsening chronic pain (CP) and even the development of new pain cases. The objective of this study was to make a mini-review CP prevalence during the pandemic. Peer-reviewed scientific articles, including reviews and case reports, were researched. In the following bases: MEDLINE/Pubmed, EMBASE e Google Academic. Gray literature was also searched, including: Google Academic, bioRxiv and medRxiv. Search period: from February to October 2020, using the search terms ("chronic pain" AND "coronavirus" OR "COVID-19"). In one survey conducted by the Spanish Pain Society, 57\% (151/264) of participants reported worsening $\mathrm{CP}$ during the pandemic. However, they did not investigate new cases of pain during this period. To our knowledge, this is the first review in on CP prevalence during the COVID-19 outbreak. Although an increase in CP prevalence would be expected, we have not found any study on this subject.

Keywords: dor crônica, COVID-19, prevalência.

Correspondência

Vithória Vidotti Neves

Rua Mariz e Barros, 775

20270-901 - Maracanã/RJ

Brasil

E-mail: vithoriavid@gmail.com
${ }^{1}$ Departamento de Medicina Interna, Hospital Universitário Gaffrée e Guinle, Universidade Federal do estado do Rio de Janeiro, RJ, Brasil. ${ }^{2}$ Programa de Pós-graduação de Neurologia, Departamento de Neurologia, Hospital Universitário Gaffrée e Guinle, Universidade Federal do estado do Rio de Janeiro, RJ, Brasil. ${ }^{3}$ Gerência de Ensino e Pesquisa, Hospital Universitário Gaffrée e Guinle, Universidade Federal do estado do Rio de Janeiro, EBSERH, Rio de Janeiro, RJ, Ministério da Educação e Cultura, Brasil. 


\section{INTRODUCTION}

Chronic pain (CP) has been highlighted as one of the most prominent causes of disability worldwide. It is defined as pain that persists after the normal period for lesion healing and continues for at least three months ${ }^{1}$. As described in other countries, CP is highly prevalent in $\mathrm{Brazil}^{2}$. Additionally, it is well known that psychosocial stressors increase CP's prevalence ${ }^{3}$.

In this sense, the current COVID-19 outbreak has many characteristics that could lead to the worsening of $\mathrm{CP}$ and even the development of new pain cases. Therefore, an increase in the CP rate would be associated with the current pandemic advent. The present study aimed to review the literature on $\mathrm{CP}$ prevalence during the COVID-19 outbreak.

\section{METHODS}

\section{Search Strategy}

Studies were obtained by searching for original articles, editorials, reviews, correspondence and case-report studies. The search was performed in MEDLINE/Pubmed, EMBASE and Google Scholar from February to October 2020, using the search terms ("chronic pain" AND "coronavirus" OR "COVID-19”). In addition, non-peer-reviewed articles were also searched in the following bases: bioRxiv, medRxiv and Google Scholar. The reference lists of the selected studies were examined for further relevant studies. We did not apply any language restrictions to our search. Studies with CP related to COVID-19 as part of a postviral syndrome or the result of viral-associated organ damage were excluded.

\section{RESULTS}

In MEDLINE/Pubmed and EMBASE databases, 16 studies $^{4-19}$ met the inclusion criteria (table I). Thirteen reports were published in English and three in Spanish.

We included 6 reviews, 5 editorials and 3 letter to the Editor. Javed et al. (2020) ${ }^{4}$ speculated that psychological impact and social isolation could favor the CP exacerbation. However, we did not find any peer reviewed article that favored this hyphothesis.

Table 1

\begin{tabular}{|c|c|}
\hline Authors & Type of study \\
\hline Javed et al. ${ }^{4}$ & Editorial \\
\hline Clauw et al. ${ }^{5}$ & Review \\
\hline El-Tallawy et al. ${ }^{6}$ & Review \\
\hline Shanthanna et al. ${ }^{7}$ & Review \\
\hline Karos et al. ${ }^{8}$ & Review \\
\hline Piraccini et al. ${ }^{9}$ & Letter to the Editor \\
\hline Spanish Pain Society ${ }^{10}$ & Gray Literature \\
\hline Kemp et al. ${ }^{11}$ & Editorial \\
\hline Eccleston et al. ${ }^{12}$ & Review \\
\hline Lambert, David. ${ }^{13}$ & Letter to the Editor \\
\hline Jha et al. ${ }^{14}$ & Letter to the Editor \\
\hline Segura, J.A. ${ }^{15}$ & Editorial \\
\hline Vasconcelos, A. ${ }^{16}$ & Editorial \\
\hline DeSantana JM. ${ }^{17}$ & Editorial \\
\hline Fallon et al. ${ }^{18}$ & Literatura Cinza \\
\hline Gharaei et al. ${ }^{19}$ & Revisão \\
\hline
\end{tabular}

We found only one study published in the bioRxiv. Fallon et al. (2020) investigated how lockdown restrictions in the United Kingdom impacted individuals with CP $(\mathrm{n}=431)$ compared to a healthy control group ( $\mathrm{n}=88$ ). This study revealed an increase in the subjecti- ve perception of pain during the lockdown period. The researchers did not examine the $\mathrm{CP}$ prevalence during the current pandemic ${ }^{18}$.

We also found one survey conducted by the Spanish Pain Society ${ }^{10}$. In this survey, most participants $(57 \%, 151$ out of 264) responded 
that the perception of pain was worse in pandemic as compared to the perception before the pandemic. However, they did not report the rate of $\mathrm{CP}$ new cases during the pandemic.

\section{DISCUSSION}

The present review sheds light on the importance of new studies on CP prevalence in the COVID-19 outbreak. Although an increase in the pain prevalence would be expected, we have not found any refereed study on CP prevalence during the current pandemic. Furtther investigation should be performed using a broader search to confirm this result.

The COVID-19 causes devastating psychosocial effects and health problems

\section{REFERÊNCIAS}

1. 1. International association for the study of pain. Pain, v. 26, n. 3, p. 1-8, 1986.

2. Appolinario JC, Teixeira MJ, Dias R, Latorre DO. Prevalence of chronic pain in a metropolitan area of a developing country: a population-based study. 2016; 990-8.

3. Meints SM, Edwards RR. Evaluating psychosocial contributions to chronic pain outcomes. Prog Neuro-Psychopharmacology Biol Psychiatry. 2018;87:168-82.

4. Javed S, Hung J, Huh BK. Impact of COVID-19 on chronic pain patients: a pain physician's perspective. Pain Manag. 2020;10(5):275-7.

5. Clauw DJ, Häuser W, Cohen SP, Fitzcharles MA. Considering the potential for an increase in chronic pain after the COVID-19 pandemic. Pain. 2020;161(8):1694-7.

6. El-Tallawy, S. N., Nalamasu, R., Pergolizzi, J. V., \& Gharibo, C. (2020). Pain Management During the COVID-19 Pandemic. Pain and therapy, 1-14.

7. Shanthanna H, Strand NH, Provenzano DA, Lobo CA, Eldabe S, Bhatia A, et al. Caring for patients with pain during the COVID-19 pandemic: consensus recommendations from an international expert panel. Anaesthesia. 2020;75(7):935-44.

8. Karos K, McParland JL, Bunzli S, Devan H, Hirsh A, Kapos FP, et al. The social threats of COVID-19 for people with chronic pain. Pain. 2020;161(10):222935.

9. Piraccini, Emanuele, Helen Byrne, and Stefania Taddei. "Chronic pain management in COVID-19 Era." Journal of clinical anesthesia 65 (2020): 109852.

10. Espa S, Dolor D. Resultados encuesta paciente dolor crónico y Covid-19. 2020; such as stress, anguish, fear, anxiety, depressive symptoms, sleep disorders, denial, anger, frustration, and distrust ${ }^{3,4}$. Studies are needed to examine whether these factors could impact the $\mathrm{CP}$ rate during the pandemic.

To our knowledge, this is the first review on the CP prevalence during the COVID-19 outbreak. Further investigations should be conducted using a broader search in order to confirm this finding.

\section{CONCLUSION}

Our preliminary literature search indicated a lack of systematic studies on CP prevalence during the current COVID-19 pandemic.

11. Kemp HI, Corner E, Colvin LA. Chronic pain after COVID-19: implications for rehabilitation. Br J Anaesth. 2020;125(4):436-40.

12. Eccleston C, Blyth FM, Dear BF, Fisher EA, Keefe FJ, Lynch ME, et al. Managing patients with chronic pain during the COVID-19 outbreak: considerations for the rapid introduction of remotely supported (eHealth) pain management services. Pain. 2020;161(5):889-93.

13. Lambert, David. "Opioids and the COVID-19 pandemic: does chronic opioid use or misuse increase clinical vulnerability?" BJA: British Journal of Anaesthesia (2020).

14. Jha S, Shah S, Lubrano M. Caring for vulnerable chronic pain patients during the time of covid. Pain Physician. 2020; 23: S459-60.

15. Segura JAM. Coronavirus COVID-19 y dolor crónico: incertidumbres. Departamento de Neurociencias Facultad de Medicina Universidad de Cádiz, España. 2020;72-3.

16. Vasconcelos AAM y SRP de. COVID-19 y dolor crónico: muchos interrogantes y pocas certezas COVID-19 and chronic pain: Many questions and few certainties. 2020;46(6):365-7.

17. DeSantana JM. What about patients with pain during and after the COVID-19 pandemic? BrJP São Paulo, 2020. 2020;3(3): 292-3.

18. Fallon N, Brown C, Twiddy H, Brian E, Frank B, Nurmikko T, et al. Adverse effects of COVID-19 related lockdown on pain, physical activity and psychological wellbeing in people with chronic pain 1. 2020;44(0): 1-25.

19. Gharaei H, Diwan S. Covid-19 pandemic: Implications on interventional pain practice - a narrative review. Pain Physician. 2020;23: S311-8. 


\title{
Covid-19 Causa Alterações Atencionais a Longo Prazo
}

\author{
Aureo do Carmo Filho ${ }^{1}$, Eelco van Duinkerken ${ }^{1,2}$, Sergio Luis Schmidt ${ }^{1}$
}

\begin{abstract}
RESUMO
Introdução: Alterações atencionais relacionadas a COVID-19 foram relatadas em poucos estudos até agora, mas ainda não está claro se estas alterações, presentes na fase aguda da doença, regridem ou persistem por longo prazo. Métodos: Estudo transversal com pacientes egressos da Unidade Covid do Hospital Universitário Gaffrée e Guinle, com pesquisa positiva para RT-PCR em amostra de swab de nasofaringe para SARS-Cov-2. Pacientes e controles foram submetidos a um teste computadorizado de atenção que fornece número de erros de omissões e comissões bem como tempo de reação e sua respectiva variabilidade. Resultados: Pacientes com COVID-19 apresentaram resultados piores que o grupo controle. As diferenças nos números de omissões e comissões não mostraram uma magnitude de importância neuropsicológica, entretanto, as médias dos tempos de reação e da variabilidade dos tempos de reação dos pacientes foram significativamente maiores. Conclusões: Nossos achados indicam que há comprometimento atencional em pacientes graves e críticos com COVID-19 três meses após a alta hospitalar. São necessários estudos longitudinais com testagens periódicas para melhor avaliação da evolução do comprometimento atencional em pacientes acometidos pela COVID-19.

Palavras-chave: COVID-19, atenção, testes neuropsicológicos.
\end{abstract}

\section{Covid-19 Leave Long-Term Attention Impairment}

\begin{abstract}
Introduction: Attentional impairment related to COVID-19 have been reported in few studies so far, but it is still unclear whether these changes, present in the acute phase of the disease, regress or persist for the long term. Methods: Cross-sectional study with patients discharged from the Covid Unit of the Hospital Universitário Gaffrée e Guinle, with positive research for RT-PCR in a nasopharyngeal swab sample for SARS-Cov-2. Patients and controls underwent a computerized attention test that provides a number of errors of omissions and commissions, as well as reaction time and their respective variability. Results: Patients with COVID-19 showed worse results than the control group. Group differences in the numbers of omissions and commissions did not reach significance. However, group differences reached statistical significance for reaction times and variability of the reaction times. Conclusions: Our findings indicate that there is an attentional impairment in critically ill patients with COVID-19 three months after hospital discharge. Longitudinal studies with periodic attention tests are necessary to better assess the evolution of the deficits in patients affected by COVID-19.
\end{abstract}

Keywords: COVID-19, attention, neuropsychological tests.

\footnotetext{
${ }^{1}$ Programa de Pós-Graduação em Neurologia, Departamento de Neurologia, Hospital Universitário Gaffrée e Guinle, Universidade Federal do Estado do Rio de Janeiro, Rio de Janeiro, RJ, Brasil. ${ }^{2}$ Departamento de Psicologia Médica, Amsterdam University Medical Centers, VU University, Amsterdam, Holanda. Centro de Diabetes de Amsterdam / Departamento de Medicina Interna, Centros Médicos da Universidade de Amsterdam, Universidade VU, Amsterdam, Holanda.

\author{
Correspondência \\ Aureo do Carmo Filho \\ Rua Mariz e Barros, 775 \\ 20270-901 - Maracanã/RJ \\ Brasil \\ E-mail: aureocf@gmail.com
}




\section{INTRODUCTION}

Previous studies have reported a wide spectrum of signs and symptoms associated with COVID-19. More than 35\% of patients present neurological symptoms. It has been proposed that these symptoms were related to cerebral hypoxia resulting from respiratory failure ${ }^{1}$.

Attentional impairment has been reported in COVID-19 patients $^{2,3}$, but it is still unclear whether these changes, persist for a long term.

Here, we assessed attentional performance 2-3 months after severe/critical symptoms of SARS-Cov-2 infection.

\section{METHODS}

Participants: Observational, cross-sectional study with 20 patients discharged from the Covid Unit of the Gaffrée and Guinle Unversity Hospital, with positive RT-PCR for SARS-Cov-2. The control group was composed of 28 asymptomatic and known to be negative for PCR research for SARS-Cov-2.

They agreed to participate in this study and signed an Informed Consent. This research was approved by the institution's Research Ethics Committee.

Exclusion criteria: Patients with dementia, $>60$ years of age, and those with history of altered mental status. We also excluded patients who showed an altered breathing pattern in the last 7 days preceding the outpatient consultation. Procedures: The individuals were submitted to an interview to collect demographic and epidemiological data. At the same time, the computerized visual attention test (CVAT) was performed. COVID-19 group was evaluated 80 to 90 days after hospital discharge. Control group was tested from June to August/2020.

The CVAT is validated in Brazil. It is independent of the educational level and has no learning effect upon retests. It is a go/no-go test in which alternate figures (targets or non-tar- gets) are randomly presented on the computer screen. The subjects must press the space key on the keyboard, as quick as possible, each time the target is shown. Then, the number of omission errors (times when the participant fails to activate the keyboard when the target appears), commission errors (activation of the keyboard when the non-target appears), average reaction time for correct responses and variability of correct reaction times. It lasts 90 seconds and has already been applied in different clinical situations $^{4-9}$.

Group differences were analyzed analyzed with the use of a Multivariate analysis of covariance (MANCOVA) followed by ANCOVAs (univariate analysis of covariance).

\section{RESULTS}

Our sample was initially composed of 25 patients. One patient was excluded from the study for presenting the diagnosis of dementia and another 4 for being over 60 years of age. The control group consisted of 28 individuals.

The female gender was the majority in both groups and the age ranged from 22 to 60 years (Table 1$)$. For all the variables of the CVAT, COVID-19 group performed poorer when compared to control group (Table 1). The overall MANCOVA, after correction for age and sex was statistically significant $(\mathrm{F}=2.84$, $\mathrm{df}=$ $4 / 41, \mathrm{P}=0.036)$, which indicated that at least one variable was different between the groups. Further analysis using post-hoc ANCOVA showed that the mean intraindividual variability of reaction times for the correct responses was significantly higher in the COVID-19 group (92.05 $\pm 36.12 \mathrm{~ms}$ versus $62.86 \pm 15.53 \mathrm{~ms}, \mathrm{~F}=10.74$, $\mathrm{df}=1 / 44, \mathrm{P}=0.002)$ as well the Reaction time (406.65 \pm 52.83 vs. $367.96 \pm 38.22 \mathrm{~ms}, \mathrm{~F}=6.25$, $\mathrm{dF}=1 / 44, \mathrm{P}=0.016$ ) (Figure 1). Group differences in the total number or commission and omission errors did not reach significance. 
Table 1. Groups characteristics

\begin{tabular}{lccc}
\hline & COVID-19 & Control & p \\
\hline Age & $39.4 \pm 9.8$ & $45.4 \pm 8.8$ & 0.549 \\
Sex (female/male; \%female) & $12 / 8(60)$ & $28 / 20(71.4)$ & 0.150 \\
Reaction time (ms) & $406.65 \pm 52.83$ & $367.96 \pm 38.22$ & $\mathbf{0 . 0 0 2}$ \\
Variability of reaction time (ms) & $92.05 \pm 36.12$ & $62.86 \pm 15.53$ & $\mathbf{0 . 0 1 6}$ \\
Omission errors (min-max) & $1.60(0-10)$ & $1.29(0-21)$ & 0.842 \\
Comission errors (min-max) & $2.95(0-10)$ & $2.21(0-10)$ & 0.318 \\
\hline
\end{tabular}

Figure 1. Boxplot graphs of the mean reaction time of the correct responses and mean variability of all reaction times of the correct responses. Blue boxes depict control group and red boxes represent COVID-19 patients
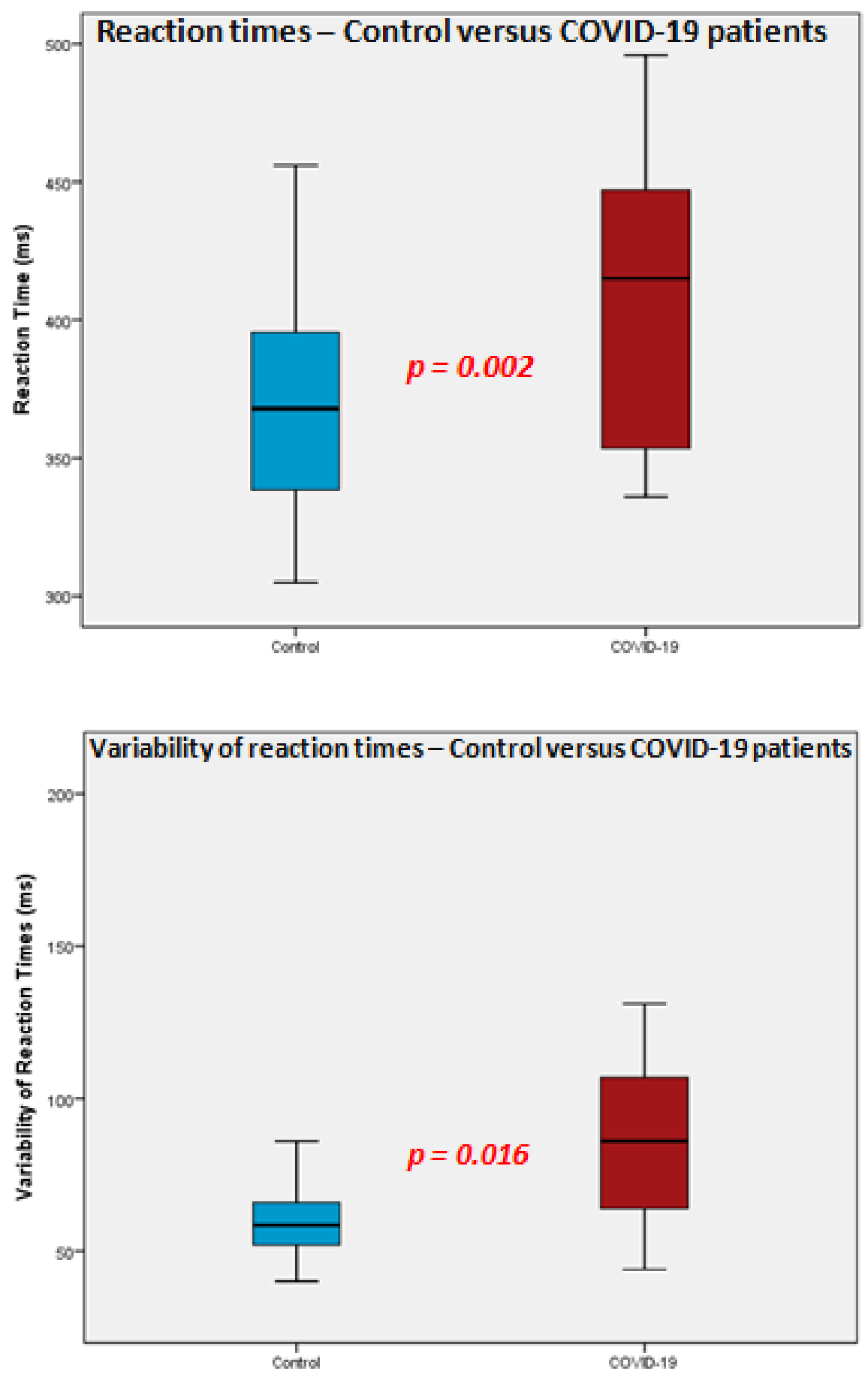


\section{DISCUSSION}

Attentional impairment was described in COVID-19. This is the first description of later attention deficits in patients who required hospitalization in intensive care (severely and / or critically ill patients).

The attention test was done in our patients about 3 months after their discharge. We observed a higher reaction times and variability of reaction times in COVID-19 patients as compared to the control group.

One limitation of our study is the statisti-

\section{REFERÊNCIAS}

1. Niazkar, H.R., Zibaee, B., Nasimi, A. et al. The neurological manifestations of COVID-19: a review article. Neurol Sci 41, 1667-1671 (2020). https://doi. org/10.1007/s10072-020-04486-3.

2. Zhou, H., Lu S., Chen J., Wei, N. et al. J Psychiatr Res. 129, 98-102 (2020) doi: 10.1016/j.jpsychires.2020.06.022.

3. Tolentino, J.C.; Gjorup, A.L.T.; Schmidt, G.J.; Schmidt, S.L. Early Attention Impairment in a Patient with COVID-19. Preprints 2020, 2020070271 (doi: 10.20944/preprints202007.0271.v1).

4. Schmidt, Guilherme J. et al. Detection of Cognitive Dysfunction in Elderly with a Low Educational Level Using a Reaction-Time Attention Task. J Alz Dis 1 Jan. 2020 : 1 - 9. (doi: 10.3233/JAD-200881).

5. Schmidt SL, Schmidt GJ, Padilla CS, Simões EM, Tolentino JC, Barroso PR, Narciso JH, Godoy ES, Costa Filho RL. Decrease in Attentional Performance After Repeated Bouts of High Intensity Exercise in Association-Football Referees and As- cal power due to the small sample size. A second limitation was the absence of attentional assessments during the patients' hospitalization, which would allow a better comparison of the attentional performance during the evolution of the disease.

\section{CONCLUSIONS}

Our findings suggest that attentional impairment persists even 3 months after the acute phase of COVID-19 in severe and critically ill patients.

sistant Referees. Frontiers in Psychology, v. 10, p. 01-16, 2019.

6. Schmidt SL; Silva MS, Schmidt GJ, Carvalho ALN, Vasconcelos CCF, Paes RA, Boechat Y, Neder R, Alvarenga RP. Neuropsychiatric assessments in patients with multiple sclerosis in early phases and with low disability. Neuropsychiatric Disease and Treatment, v. 14, p. 1665-1670, 2018.

7. Simões EM, Padilla CS, Bezerra MLS, Schmidt SL. Analysis of attention subdomains in obstrutive sleep apnea patients. Frontiers in Psychiatry, v. 2018, p. 1-10, 2018.

8. Schmidt GJ, Alvarenga, R, Manhães AC, Schmidt SL. Attentional performance may help to identify duloxetine responders in chronic pain fibromyalgia patients. EUROPEAN JOURNAL OF PAIN, v. 21, p. 977-986, 2017.

9. Schmidt G, Boechat Y, Schmidt S. Distinguishing early stage Alzheimer's disease from mild cognitive impairment using a quick and cultural free computerized attention test. doi:10.1016/j.jns.2017.08.2196. 


\title{
Manifestações Otorrinolaringológicas na COVID-19
}

Amanda Dal Castel Ferreira da Silva ${ }^{1}$, Michelly da Silva Nascimento de Farias $^{1}$, Alice Zopelar Almeida de Oliveira Pena ${ }^{1}$, João Vitor Camargo de Abreu Silva ${ }^{1}$, Manuella Caroline Dutra Frazão Alves ${ }^{1}$, Alexia de Almeida Reis Rodrigues ${ }^{1}$, Jorge da Cunha Barbosa Leite ${ }^{2}$

\section{RESUMO}

Proposta: $\mathrm{O}$ acometimento das vias aéreas superiores pelo novo coronavírus torna importante a análise das manifestações otorrinolaringológicas(ORL) na COVID-19. Então, foi feita avaliação da frequência absoluta dos sintomas ORL nos pacientes adultos infectados pelo SARS-CoV-2. Métodos: Foram buscados artigos nas plataformas PubMed, SciELO e LILACS utilizando-se palavras chaves relacionadas a alterações otorrinolaringológicas e COVID-19. Resultados: Foram escolhidos e usados 17 artigos como fonte de dados para a revisão. Totalizaram-se 2.371 pacientes testados positivos para COVID-19 (54,7\% do sexo feminino). Desses, $49,5 \%$ apresentaram disfunção de olfato e/ou paladar, $27,7 \%$ odinofagia, entre $17,2 \%$ e $18,5 \%$ congestão nasal, $16,8 \%$ disfagia e entre $14,6 \%$ e $15,8 \%$ rinorreia. Demais sintomas ORL estiveram presentes em porcentagens menores que 15\% cada. Conclusão: A disfunção de olfato e/ou paladar e a odinofagia foram manifestações de maior ocorrência. Entretanto, verificou-se a presença de outros sintomas otorrinolaringológicos que podem estar associados à COVID-19. Estes sintomas poderiam alertar o médico generalista sobre a possibilidade de infecção pelo SARS-CoV-2, mesmo na ausência das manifestações comuns da doença.

Palavras-chave: otolaringologia, sinais e sintomas, SARS-CoV-2.

\section{Ear, Nose and Throat Manifestations at COVID-19}

\begin{abstract}
Purpose: The involvement of the upper airways by the new coronavirus makes the analysis of ear, nose and throat (ENT) manifestations important in COVID-19. Thus, an evaluation was made of the absolute frequency of ENT symptoms in adult patients infected with SARS-CoV-2. Methods: Articles were searched on the plataforms PubMed, SciELO and LILACS, using keywords related to ENT outcomes and COVID-19. Results: Seventeen articles were chosen and used as database to the review. 2,371 pacients tested positive to COVID-19 (54.7\% female). Of these, $49.5 \%$ presented olfatory and/or gustatory disfunction, $27.7 \%$ odinophagy, between $17.2 \%$ and $18.5 \%$ nasal congestion, $16.8 \%$ dysphagia and between $14.6 \%$ and $15.8 \%$ rhinorrea. Other ENT symptoms were presented in percentages fewer than $15 \%$ each.
\end{abstract}

${ }^{1}$ Alunos de graduação do Curso de Medicina da Escola de Medicina e Cirurgia (EMCUNIRIO) - Hospital Universitário Gaffrée e Guinle, Rio de Janeiro, Brasil. ²Professor associado da Disciplina de ORL da Escola de Medicina e Cirurgia (EMC-UNIRIO) Hospital Universitário Gaffrée e Guinle, Rio de Janeiro, Brasil.

Correspondência

Jorge da Cunha Barbosa Leite

Rua Mariz e Barros, 775

20270-901 - Maracanã/RJ

Brasil

E-mail: jorgeleite@otologia.com. br 
Conclusion: Olfatory and/or gustary disfunction and odinophagya were the manifestions with highest occurence. However, other ENT symptoms that may be associated with COVID-19 were found. These symptoms could alert the general practitioner about the possibility of SARS-CoV-2 infection, even in the absence of the common manifestations of the disease.

Keywords: otolaryngology, signs and symptoms, SARS-CoV-2. 


\section{INTRODUCTION}

The Coronavirus Disease 2019 (COVID-19) has several clinical manifestations, which occur in different forms and degrees of severity $^{1,2}$. The most reported symptoms are fever, cough and fatigue ${ }^{3-8}$.

Viral involvement of upper respiratory system has led researchers to study ENT disorders at COVID-19, demonstrating the importance of symptoms such as rhinorrhea, nasal obstruction, otalgia, cochlear-vestibular and chemosensory changes, odynophagia and dysphagia $^{9-17}$.

\section{OBJECTIVES}

To evaluate the absolute frequency of ENT symptoms in adult patients infected with SARS-CoV-2.

\section{METHODS}

Articles published until August 30, 2020, were collected in the PubMed, SciELO and LILACS. Keywords ENT, ENT manifestations, ORL, ORL manifestations, otorhinolaryngology, otorhinolaryngologic manifestations, ear, nose, throat, laringe, larynx, laringea, pharinge, pharynx, nasal, nasal obstruction, runny nose, rhinorrhea, sore throat, pharyngalgia, sinusitis, pharyngitis, voice disorder, hoarseness, hearing loss, deafness, tinnitus, ear ache, otalgia, smell dysfunction,anosmia, dysgeusia, hyposmia, smell and taste were searched using connective "OR" and associated with "AND" to COVID,COVID-19, coronavirus, SARS-CoV-2 and 2019-nCoV.

Articles with full available text were selected. Inclusion criteria were: written in English or Portuguese; indicate the individuals' ENT symptoms; not only presenting serious and/or critical patients; a minimum of 50 patients and be a cohort, cross-sectional or case series study.

Exclusion criteria: absence of testing for SARS-CoV-2; failure showing the number of people affected by the symptoms; age below 18 years; patients with impaired sense of smell and/or taste as an inclusion criterion in the study; dysfunction of smell and/or taste as the only ENT symptom and studies with the same data source in the same period of time.

\section{RESULTS}

Seventeen articles were selected, the analysis included 2,371 patients, 54.7\% female (Table 1). The distribution of ENT symptoms and specific details of manifestations in the sense of smell and taste are described, respectively, in tables 2 (two parts) and 3.

Table 1. Characteristics of the articles

\begin{tabular}{|c|c|c|c|c|}
\hline Author & Location & Number of pacients & Male & Female \\
\hline Shahriarirad et al. ${ }^{18}$ & Iran & 113 & 71 & 42 \\
\hline Biadsee et al. ${ }^{19}$ & Israel & 128 & 58 & 70 \\
\hline Chary et al. ${ }^{20}$ & France & 115 & 34 & 81 \\
\hline Mohamud et al. ${ }^{21}$ & Somalia & 60 & 42 & 18 \\
\hline S. Bastrup Israelsen et al. ${ }^{22}$ & Denmark & 175 & 85 & 90 \\
\hline C. Liguori et al. ${ }^{23}$ & Italy (Rome) & 103 & 59 & 44 \\
\hline Vaira et al. ${ }^{24}$ & Italy (Sassari) & 72 & 27 & 45 \\
\hline F. Freni et al. ${ }^{25}$ & Italy (Messina) & 50 & 30 & 20 \\
\hline C. Corsini Campioli et al. ${ }^{26}$ & USA (Minnesota) & 251 & 103 & 148 \\
\hline Lan et al. ${ }^{27}$ & USA (Massachusetts) & 83 & 23 & 60 \\
\hline E. Sakalli et al. ${ }^{28}$ & Turkey (Istambul) & 172 & 84 & 88 \\
\hline Salepci et al. ${ }^{29}$ & Turkey (Istambul) & 223 & 113 & 110 \\
\hline Lechien et al. ${ }^{30}$ & Spain, Belgium, France and Italy & 417 & 154 & 263 \\
\hline $\mathrm{Xu}$ et $\mathrm{al}^{31}$ & China (Guangdong) & 90 & 39 & 51 \\
\hline Wang et al. ${ }^{32}$ & China (Wuhan, Hubei) & 138 & 75 & 63 \\
\hline Han et al. ${ }^{33}$ & China (Wuhan, Hubei) & 108 & 38 & 70 \\
\hline \multirow[t]{3}{*}{ Zheng et al. ${ }^{34}$} & China (Shiyan, Hubei) & 73 & 40 & 33 \\
\hline & Total & 2.371 & 1.075 & 1.296 \\
\hline & $(\%)$ & & $45.3 \%$ & $54.7 \%$ \\
\hline
\end{tabular}


Table 2. ENT symptoms: part one

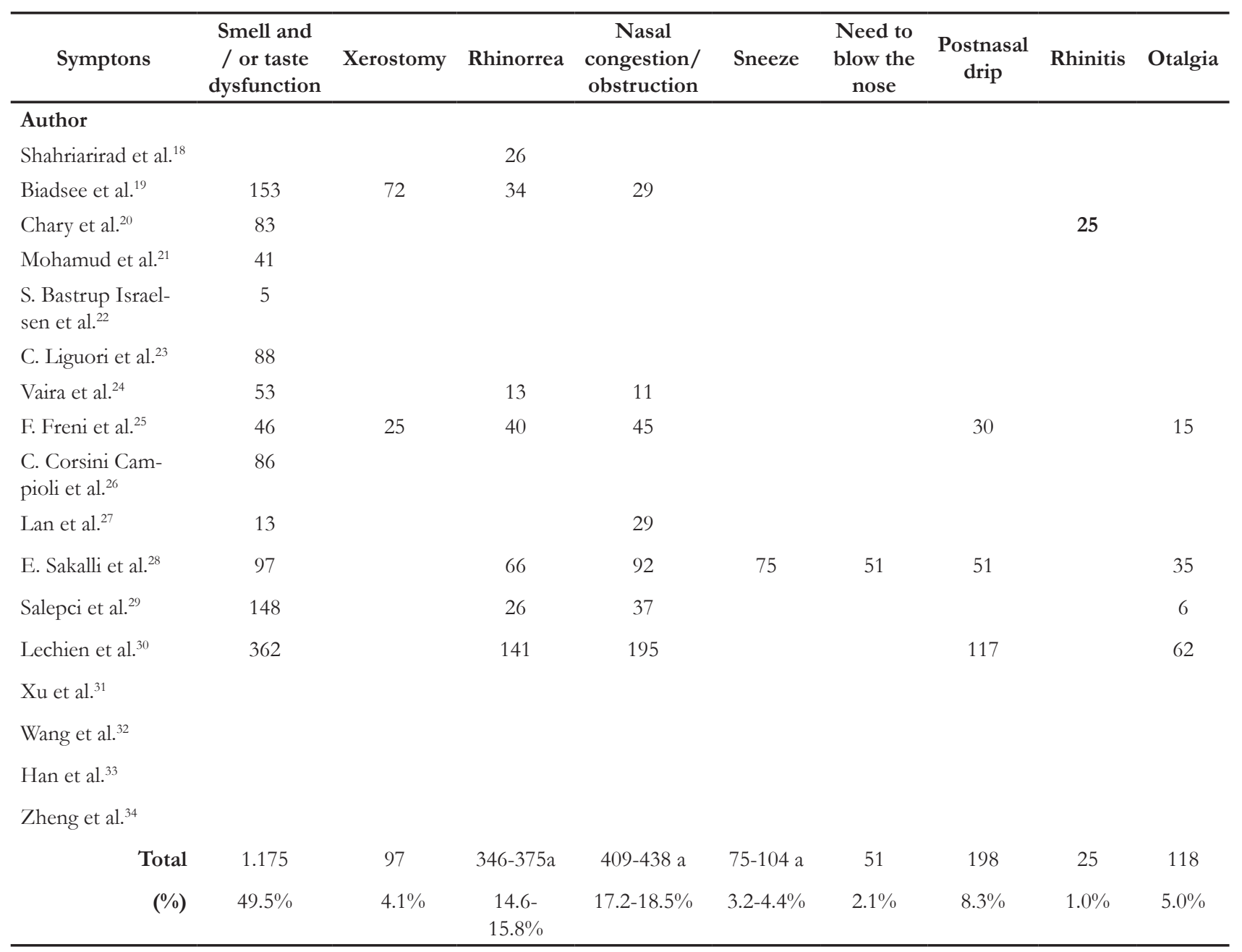

${ }^{a}$ In the following article, there was no separation between the symptoms rhinorrhea, nasal obstruction and sneezing; therefore, the possibility of having a greater or lesser number of total patients with each of these symptoms was taken into account in the total. 
Table 2. ENT symptoms: part two

\begin{tabular}{|c|c|c|c|c|c|c|c|c|c|}
\hline Symptoms & $\begin{array}{l}\text { Plugged } \\
\text { ear sen- } \\
\text { sation }\end{array}$ & $\begin{array}{l}\text { Hearing } \\
\text { dysfunc- } \\
\text { tion }\end{array}$ & $\begin{array}{l}\text { Vestibular } \\
\text { disorder }\end{array}$ & $\begin{array}{l}\text { Face } \\
\text { pain }\end{array}$ & $\begin{array}{c}\text { Chewing } \\
\text { muscle } \\
\text { myalgia }\end{array}$ & Dysphonia & Odinophagy & Dysphagia & $\begin{array}{c}\text { Dry } \\
\text { throat }\end{array}$ \\
\hline \multicolumn{10}{|l|}{ Author } \\
\hline Shahriarirad et al. ${ }^{18}$ & & & & & & & 36 & & \\
\hline Biadsee et al. ${ }^{19}$ & & & & 18 & 15 & & 34 & & \\
\hline Chary et al..$^{20}$ & & & & & & & 21 & & \\
\hline Mohamud et al..$^{21}$ & & & & & & & 15 & & \\
\hline $\begin{array}{l}\text { S. Bastrup Israel- } \\
\text { sen et al. }\end{array}$ & & & & & & & 31 & & \\
\hline C. Liguori et al..$^{23}$ & & 2 & 27 & & & & & & \\
\hline Vaira et al. ${ }^{24}$ & & & & & & & 37 & & \\
\hline F. Freni et al. ${ }^{25}$ & & & & 30 & & 7 & 27 & 46 & \\
\hline $\begin{array}{l}\text { C. Corsini Cam- } \\
\text { pioli et al. }{ }^{26}\end{array}$ & & & 28 & & & & 79 & & \\
\hline Lan et al. ${ }^{27}$ & & & & & & & 38 & & \\
\hline E. Sakalli et al. ${ }^{28}$ & 31 & & 29 & 43 & & & 86 & & \\
\hline Salepci et al..$^{29}$ & & 2 & 5 & 24 & & & 58 & & 36 \\
\hline Lechien et al..$^{30}$ & & & & 153 & & & 129 & 353 & \\
\hline Xu et al. ${ }^{31}$ & & & & & & & 23 & & \\
\hline Wang et al. ${ }^{32}$ & & & 13 & & & & 24 & & \\
\hline Han et al. ${ }^{33}$ & & & & & & & 14 & & \\
\hline Zheng et al. ${ }^{34}$ & & & & 1 & & & 6 & & \\
\hline Total & 31 & 4 & 102 & 269 & 15 & 7 & 658 & 399 & 36 \\
\hline$(\%)$ & $1.3 \%$ & $0.2 \%$ & $4.3 \%$ & $11.3 \%$ & $0.6 \%$ & $0.3 \%$ & $27.7 \%$ & $16.8 \%$ & $1.5 \%$ \\
\hline
\end{tabular}


Table 3. Description of smell and taste disorders

\begin{tabular}{|c|c|c|}
\hline Articles & Smell disorders (S. D.) & Taste disorders (T. D.) \\
\hline \multirow[t]{2}{*}{ Biadsee et al. ${ }^{19}$} & 86 & 67 \\
\hline & $\begin{array}{l}19.5 \% \text { of patients with S. D. had anos- } \\
\text { mia. }\end{array}$ & $\begin{array}{l}52 \text { patients showed changes in the perception of } \\
\text { spicy taste, } 54 \text { in salty taste, } 53 \text { in sour taste and } \\
61 \text { in sweet taste. }\end{array}$ \\
\hline S. Bastrup Israelsen et al. ${ }^{22}$ & - & 5 \\
\hline C. Corsini Campioli et al. ${ }^{26}$ & 45 & 41 \\
\hline \multirow[t]{2}{*}{ E. Sakalli et al. ${ }^{28}$} & 88 & 81 \\
\hline & $\begin{array}{l}-2 \text { patients had mild forms of S. D., } 24 \\
\text { had moderate forms and } 62 \text { severe forms. } \\
-36 \% \text { of patients with S. D. had anosmia. }\end{array}$ & $\begin{array}{l}\text { - } 72 \text { patients presented T. D. and S.D during the } \\
\text { disease. } \\
\text { - } 11 \text { had a mild form of the T. D., } 18 \text { had a mode- } \\
\text { rate form and } 52 \text { had a severe form. } \\
-30.2 \% \text { of patients with T. D. had ageusia. }\end{array}$ \\
\hline \multirow[t]{3}{*}{ Chary et al..$^{20}$} & & $83^{*}$ \\
\hline & \multicolumn{2}{|c|}{$\begin{array}{c}\text { Of the patients with dysfunction of smell and / or taste, there were: } 15 \% \text { only with anos- } \\
\text { mia, } 5 \% \text { only with hyposmia, } 2 \% \text { only with ageusia, } 5 \% \text { only with hypogeusia, } 33 \% \text { with } \\
\text { anosmia and hypogeusia, } 32 \% \text { anosmia and ageusia, } 6 \% \text { hyposmia and hypogeusia, } 1 \% \\
\text { hyposmia and ageusia. }\end{array}$} \\
\hline & $\begin{array}{l}\text { There were } 4 \text { cases of phantasmia and } 5 \\
\text { cases of cacosmia. }\end{array}$ & $\begin{array}{l}\text { There were } 4 \text { cases of parageusia } \\
\text { and } 3 \text { cases of cacogeusia. }\end{array}$ \\
\hline \multirow[t]{2}{*}{ Lan et $\mathrm{al}^{27}$} & \multicolumn{2}{|l|}{ 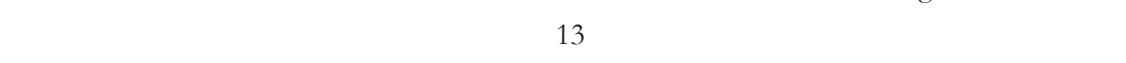 } \\
\hline & \multicolumn{2}{|c|}{ The 13 had ageusia and / or anosmia ( $15.7 \%$ of the total patients studied). } \\
\hline \multirow[t]{3}{*}{ Vaira et al. ${ }^{24}$} & 44 & 39 \\
\hline & $\begin{array}{l}34 \text { patients with anosmia, } 8 \text { with hypos- } \\
\text { mia and } 2 \text { with dysosmia. }\end{array}$ & $\begin{array}{l}-28 \text { patients with ageusia and } 11 \text { with hypogeusia. } \\
-23 \text { patients with changes in the sensation of } \\
\text { sweet taste and } 21 \text { in that of sour taste. }\end{array}$ \\
\hline & \multicolumn{2}{|c|}{$\begin{array}{l}9 \text { patients with isolated T.D., } 14 \text { patients with S.D. isolated and } 30 \text { patients with dysfunction } \\
\text { of smell and taste. }\end{array}$} \\
\hline Salepci et al. ${ }^{29}$ & 71 & 77 \\
\hline \multirow[t]{3}{*}{ Lechien et al. ${ }^{30}$} & 357 & 342 \\
\hline & $\begin{array}{l}284 \text { anosmia and } 73 \text { hyposmia } \\
\text { There were patients with phantasmia } \\
\text { and parosmia. }\end{array}$ & $78.9 \%$ with hyposmia and $21.1 \%$ with dysgeusia. \\
\hline & \multicolumn{2}{|c|}{20 patients with S.D. isolated, 5 with isolated T.D. and 337 with S.D. and T.D. } \\
\hline C. Liguori et al. ${ }^{23}$ & 40 (hyposmia) & 48 (dysgeusia) \\
\hline \multirow[t]{2}{*}{ F. Freni et al. ${ }^{25}$} & 46 & 35 \\
\hline & 21 with anosmia and 25 with hyposmia. & $8 \%$ hypogeusia, $42 \%$ ageusia and $16 \%$ dysgeusia. \\
\hline Mohamud et al..$^{21}$ & 24 & 17 \\
\hline
\end{tabular}

*No separation between smell and taste disorders.

\section{DISCUSSION}

ENT symptoms of COVID-19 occur due to nasal and nasopharyngeal involvement, the main entrance sites for SARS-CoV- $2^{35}$.The predominant viral presence in the nasal mucosa in relation to the throat ${ }^{36}$ highlights the importance of nasal cavity in disease's pathophysiology, allowing the association of symptoms such as rhinorrhea, nasal congestion, sneezing and olfactory and gustatory dysfunction.

The majority of nasal signs and symp- toms, excluding smell dysfunction, nasal congestion and rhinorrhea, were not prevalent. Less than $10 \%$ of patients were affected by sneezing, need to blow their nose or postnasal drip, while nasal congestion (17.2\% to $18.5 \%$ of occurrence) and rhinorrhea (14.6\% to $15.8 \%$ of occurrence) were, respectively, third and fifth most prevalent ENT symptoms.

In a study focused on nasosinusal dysfunction in COVID-19 $9^{37}$, excluding changes in smell, a low significance of nasal symptoms was identi- 
fied. This is probably due to the predilection of the virus to olfactory mucosa, due to the presence of Angiotensin-Converting Enzyme 2 (ACE2) 38 in this epithelium, a molecule that facilitates viral invasion. Corroborating this hypothesis, studies report a significant lack of relationship between loss of smell and other nasal symptoms ${ }^{13}$ and significant association between non-olfactory nasal symptoms and negative tests for SARS-CoV- $2^{27}$.

Smell and taste changes were the most common manifestations (49.5\% of complaints). The main reported changes were anosmia, hyposmia, ageusia and hypogeusia, but there were also reports of dysnomy, phantasmia, cacosmia, parageusia, cacogeusia and dysgeusia. In articles with separation between smell and taste, smell dysfunction associated with taste was more present, followed by isolated olfactory dysfunction and isolated taste dysfunction ${ }^{20,27,28}$. These changes are prevalent in mild-to-moderate disease ${ }^{20}$ and both can occur simultaneously or at different times of disease $^{28}$.

Although the pathophysiology of total or partial loss of smell and taste is incompletely known, it is believed that it can occur by two mechanisms: inflammation in olfactory mucosa causing neuroinflammation of olfactory nerve, or viral invasion of the olfactory nerve $e^{20,38-41}$. The injury caused by the virus probably shares characteristics with Wallerian degeneration, in which significant damage to the axon results in its degeneration, removal and recycling. In peripheral nervous system, Schwann cells act in regeneration and recovery of axonal function, however, the injury site is important for restructuring ${ }^{42}$. Thus, the change in smell can have a spontaneous improvement, with an average recovery time of 7.2 days $^{20}$, or generate permanent damage, impacting the life quality.

In pharyngological changes, the probable involvement of vagus and glossopharyngeal nerves has been related to the presence of dysphagia or odynophagia ${ }^{43}$. Odinophagy was the second most frequent ENT symptom (27.7\% of cases) and dysphagia affected $16.8 \%$. These data corroborate previous research with $27.6 \% 0^{44} / 26.9 \%{ }^{11}$ of patients presenting odynophagia, with significant prevalence in youth ${ }^{44}$ and sometimes being the initial symptom ${ }^{29}$.

Less than $1 \%$ of patients were dysphonic or aphonic. However, a study of 702 Europeans with mild-to-moderate COVID-19 ${ }^{45}$, showed $26.8 \%$ dysphonic, with $3.7 \%$ having aphonia. Other research has identified vocal dysfunction as a relevant prevalence symptom, with a range from $14 \%-8.4 \%{ }^{16,25,46}$. Such outcomes indicate that laryngological symptoms may have been overlooked in analyzed studies.

Otological manifestations were not prevalent, being otalgia the most reported symptom $(5 \%)$. However, previous studies reported $74.5 \% \%^{30}$ and $32.9 \%{ }^{16}$ of occurrence. Vestibular disorders were present in $4.3 \%$ of the population, while sensation of plugged ear and hearing impairment affected $1.3 \%$ and $0.2 \%$ of patients, respectively.

Underreporting of cochleovestibular symptoms can occur because changes in hearing are usually noticed after leaving hospital. According to Kevin J. Munro ${ }^{47}$, about one in ten adults reported this change when questioned up to eight weeks after hospital discharge, reducing the ability to analyze and synthesize results.

Hearing loss, tinnitus and vertigo caused by SARS-CoV-2 $2^{25,46,48}$ may occur as deleterious effects on cochlear hair cells ${ }^{49}$ or be related to damaged nervous system ${ }^{48}$. However, some drugs prescribed such as Chloroquine and Hydroxychloroquine, have ototoxic effects ${ }^{50}$.

Xerostomy (4.1\%), myalgia in the chewing muscle $(0.6 \%)$ and facial pain $(11.3 \%)$ were identified at low frequency. We can infer that such symptoms are often neglected by patients and interviewers, as they were only addressed in articles that focused on ENT changes, making their accounting difficult.

\section{CONCLUSION}

The nose and nasopharynx are the main sites of entry for SARS-CoV-2. In this way, ENT symptoms deserve attention from the general practitioner, as they have an important frequency of occurrence in adults with COVID-19: $49.5 \%$ of olfactory/gustatory changes, $27.7 \%$ odynophagia, $17.2 \%-18.5 \%$ nasal obstruction, $16.8 \%$ dysphagia and $14.6 \%-15.8 \%$ rhinorrhea. 


\section{REFERÊNCIAS}

1. Borges do Nascimento IJ, Cacic N, Abdulazeem HM, von Groote TC, Jayarajah U, Weerasekara I, et al. Novel Coronavirus Infection (COVID-19) in Humans: A Scoping Review and Meta-Analysis. J Clin Med [Internet]. 2020 Mar 30;9(4):941.

2. Ali I, Alharbi OML. COVID-19: Disease, management, treatment, and social impact. Sci Total Environ [nternet]. 2020 Aug;728:138861.

3. Huang R, Zhu L, Xue L, Liu L, Yan X, Wang J, et al. Clinical findings of patients with coronavirus disease 2019 in Jiangsu province, China: A retrospective, multi-center study. PLoS Negl Trop Dis [Internet]. 2020 May 8;14(5):e0008280.

4. Zhu J, Zhong Z, Ji P, Li H, Li B, Pang J, et al. Clinicopathological characteristics of 8697 patients with COVID-19 in China: a meta-analysis. Fam Med Community Heal [Internet]. 2020 Apr 5;8(2):e000406.

5. Wei Y, Zeng W, Huang X, Li J, Qiu X, Li H, et al. Clinical characteristics of 276 hospitalized patients with coronavirus disease 2019 in Zengdu District, Hubei Province: a single-center descriptive study. BMC Infect Dis [Internet]. 2020 Dec 29;20(1):549.

6. Yu C, Lei Q, Li W, Wang X, Liu W, Fan X, et al. Clinical Characteristics, Associated Factors, and Predicting COVID-19 Mortality Risk: A Retrospective Study in Wuhan, China. Am J Prev Med [Internet]. 2020 Aug;59(2):168-75.

7. Yang BY, Barnard LM, Emert JM, Drucker C, Schwarcz L, Counts CR, et al. Clinical Characteristics of Patients With Coronavirus Disease 2019 (COVID-19) Receiving Emergency Medical Services in King County, Washington. JAMA Netw Open [Internet]. $2020 \mathrm{Jul}$ 8;3(7):e2014549.

8. Wang R, Pan M, Zhang X, Han M, Fan X, Zhao F, et al. Epidemiological and clinical features of 125 Hospitalized Patients with COVID-19 in Fuyang, Anhui, China. Int J Infect Dis [Internet]. 2020 Jun;95:421-8.

9. Lapostolle F, Schneider E, Vianu I, Dollet G, Roche B, Berdah J, et al. Clinical features of 1487 COVID-19 patients with outpatient management in the Greater Paris: the COVID-call study. Intern Emerg Med [nternet]. 2020 Aug 30;15(5):813-7.

10. Chen Q, Zheng Z, Zhang C, Zhang X, Wu H, Wang $\mathrm{J}$, et al. Clinical characteristics of 145 patients with corona virus disease 2019 (COVID-19) in Taizhou, Zhejiang, China. Infection [Internet]. 2020 Aug 28;48(4):543-51.

11. Lechien JR, Cabaraux P, Chiesa-Estomba CM, Khalife M, Plzak J, Hans S, et al. Psychophysical Olfactory Tests and Detection of COVID-19 in Patients With Sudden Onset Olfactory Dysfunction: A Prospective Study. Ear, Nose Throat J [Internet]. 2020 May 29;014556132092916.

12. Vaira LA, Hopkins C, Salzano G, Petrocelli M, Melis A, Cucurullo $\mathrm{M}$, et al. Olfactory and gustatory function impairment in COVID-19 patients: Italian objective multicenter-study. Head Neck [Internet]. 2020 Jul 21;42(7):1560-9.

13. Jalessi M, Barati M, Rohani M, Amini E, Ourang A, Azad Z, et al. Frequency and outcome of olfactory impairment and sinonasal involvement in hospitalized patients with COVID-19. Neurol Sci [Internet]. 2020 Sep 12;41(9):2331-8.

14. Klopfenstein T, Kadiane-Oussou NJ, Toko L, Royer P-Y, Lepiller Q, Gendrin V, et al. Features of anosmia in COVID-19. Médecine Mal Infect [Internet]. 2020 Aug;50(5):436-9.

15. Joffily L, Ungierowicz A, David AG, Melo B, Brito CLT, Mello L, et al. The close relationship between sudden loss of smell and COVID-19. Braz J Otorhinolaryngol [Internet]. 2020 May;

16. Lechien JR, Cabaraux P, Chiesa-Estomba CM, Khalife M, Hans S, Calvo-Henriquez C, et al. Objective olfactory evaluation of self-reported loss of smell in a case series of 86 COVID-19 patients. Head Neck [Internet]. 2020 Jul 21;42(7):1583-90.

17. Speth MM, Singer-Cornelius T, Oberle M, Gengler I, Brockmeier SJ, Sedaghat AR. Olfactory Dysfunction and Sinonasal Symptomatology in COVID-19: Prevalence, Severity, Timing, and Associated Characteristics. Otolaryngol Neck Surg [Internet]. 2020 Jul 19;163(1):114-20.

18. Shahriarirad R, Khodamoradi Z, Erfani A, Hosseinpour H, Ranjbar K, Emami Y, et al. Epidemiological and clinical features of 2019 novel coronavirus diseases (COVID-19) in the South of Iran. BMC Infect Dis [Internet]. 2020 Dec 18;20(1):427.

19. Biadsee A, Biadsee A, Kassem F, Dagan O, Masarwa S, Ormianer Z. Olfactory and Oral Manifestations of COVID-19: Sex-Related Symptoms - A Potential Pathway to Early Diagnosis. Otolaryngol Neck Surg [Internet]. 2020 Jun 16;019459982093438.

20. Chary E, Carsuzaa F, Trijolet J-P, Capitaine A-L, Roncato-Saberan M, Fouet K, et al. Prevalence and Recovery From Olfactory and Gustatory Dysfunctions in Covid-19 Infection: A Prospective Multicenter Study. Am J Rhinol Allergy [Internet]. 2020 Sep 12;34(5):686-93.

21. Farah Yusuf Mohamud M, Garad Mohamed Y, Mohamed Ali A, Ali Adam B. Loss of Taste and Smell are Common Clinical Characteristics of Patients with COVID-19 in Somalia: A Retrospective Double Centre Study. Infect Drug Resist [Internet]. 2020 Jul; Volume 13:2631-5.

22. Bastrup Israelsen S, Tjelle Kristiansen K, Hindsberger B, Suppli Ulrik C, Andersen O, Jensen M, et al. Characteristics of patients with COVID-19 pneumonia at Hvidovre Hospital, March-April 2020. Dan Med J [Internet]. 2020 [cited 2020 Sep 25];67(6):undefined.

23. Liguori C, Pierantozzi M, Spanetta M, Sarmati L, Cesta N, Iannetta M, et al. Subjective neurological symptoms frequently occur in patients with SARS-CoV2 infection. Brain Behav Immun [Internet]. 2020 Aug;88:11-6.

24. Vaira LA, Deiana G, Fois AG, Pirina P, Madeddu G, De Vito A, et al. Objective evaluation of anosmia and ageusia in COVID-19 patients: Single-center experience on 72 cases. Head Neck [Internet]. 2020 Jun 29;42(6):1252-8.

25. Freni F, Meduri A, Gazia F, Nicastro V, Galletti C, 
Aragona P, et al. Symptomatology in head and neck district in coronavirus disease (COVID-19): A possible neuroinvasive action of SARS-CoV-2. Am J Otolaryngol [Internet]. 2020 Sep;41(5):102612.

26. Corsini Campioli C, Cano Cevallos E, Assi M, Patel R, Binnicker MJ, O’Horo JC. Clinical predictors and timing of cessation of viral RNA shedding in patients with COVID-19. J Clin Virol [Internet]. 2020 Sep;130:104577.

27. Lan F-Y, Filler R, Mathew S, Buley J, Iliaki E, Bruno-Murtha LA, et al. COVID-19 symptoms predictive of healthcare workers' SARS-CoV-2 PCR results. PLoS One [Internet]. 2020 Jun 26;15(6):e0235460.

28. Sakalli E, Temirbekov D, Bayri E, Alis EE, Erdurak SC, Bayraktaroglu M. Ear nose throat-related symptoms with a focus on loss of smell and/or taste in COVID-19 patients. Am J Otolaryngol [Internet]. 2020 Nov;41(6):102622.

29. Salepci E, Turk B, Ozcan SN, Bektas ME, Aybal A, Dokmetas I, et al. Symptomatology of COVID-19 from the otorhinolaryngology perspective: a survey of 223 SARS-CoV-2 RNA-positive patients. Eur Arch Oto-Rhino-Laryngology [Internet]. 2020 Aug 13;

30. Lechien JR, Chiesa-Estomba CM, De Siati DR, Horoi M, Le Bon SD, Rodriguez A, et al. Olfactory and gustatory dysfunctions as a clinical presentation of mild-to-moderate forms of the coronavirus disease (COVID-19): a multicenter European study. Eur Arch Oto-Rhino-Laryngology [Internet]. 2020 Aug 6;277(8):2251-61.

31. Xu X, Yu C, Qu J, Zhang L, Jiang S, Huang D, et al. Imaging and clinical features of patients with 2019 novel coronavirus SARS-CoV-2. Eur J Nucl Med Mol Imaging [Internet]. 2020 May 28;47(5):1275-80.

32. Wang D, Hu B, Hu C, Zhu F, Liu X, Zhang J, et al. Clinical Characteristics of 138 Hospitalized Patients With 2019 Novel Coronavirus-Infected Pneumonia in Wuhan, China. JAMA [Internet]. 2020 Mar 17;323(11):1061.

33. Han R, Huang L, Jiang H, Dong J, Peng H, Zhang D. Early Clinical and CT Manifestations of Coronavirus Disease 2019 (COVID-19) Pneumonia. Am J Roentgenol [Internet]. 2020 Aug;215(2):338-43.

34. Zheng Y, Xiong C, Liu Y, Qian X, Tang Y, Liu L, et al. Epidemiological and clinical characteristics analysis of COVID-19 in the surrounding areas of Wuhan, Hubei Province in 2020. Pharmacol Res [Internet]. 2020 Jul;157:104821.

35. Jian L, Yi W, Zhang N, Wen W, Krysko O, Song W-J, et al. Perspective: COVID-19, implications of nasal diseases and consequences for their management. J Allergy Clin Immunol [Internet]. 2020 Jul;146(1):679.

36. Zou L, Ruan F, Huang M, Liang L, Huang H, Hong Z, et al. SARS-CoV-2 Viral Load in Upper Respiratory Specimens of Infected Patients. N Engl J Med [Internet]. 2020 Mar 19;382(12):1177-9.

37. Lehrich BM, Goshtasbi K, Raad RA, Ganti A, Papagiannopoulos P, Tajudeen BA, et al. Aggregate Prevalence of Chemosensory and Sinonasal Dys- function in SARS-CoV-2 and Related Coronaviruses. Otolaryngol Neck Surg [Internet]. 2020 Jul 19;163(1):156-61.

38. Bilinska K, Jakubowska P, Von Bartheld CS, Butowt R. Expression of the SARS-CoV-2 Entry Proteins, ACE2 and TMPRSS2, in Cells of the Olfactory Epithelium: Identification of Cell Types and Trends with Age. ACS Chem Neurosci [Internet]. 2020 Jun 3;11(11):1555-62.

39. Mahalaxmi I, Kaavya J, Mohana Devi S, Balachandar V. COVID-19 and olfactory dysfunction: A possible associative approach towards neurodegenerative diseases. J Cell Physiol [Internet]. 2020 Jul 22;jcp. 29937.

40. Palheta Neto FX, Targino MN, Peixoto VS, Alcântara FB, Jesus CC de, Araújo DC de, et al. Anormalidades sensoriais: olfato e paladar. Arq Int Otorrinolaringol [Internet]. 2011 Sep;15(3):350-8.

41. Clemency BM, Varughese R, Scheafer DK, Ludwig B, Welch J V., McCormack RF, et al. Symptom Criteria for COVID-19 Testing of Heath Care Workers. Acad Emerg Med [Internet]. 2020 Jun 8;27(6):46974.

42. Canavarro Ferreira S, Blanco Martinez AM. O processo de degeneração walleriana e os eventos moleculares nele envolvidos - uma revisão com enfoque no sistema nervoso periférico. Fisioter Bras. 2000;1(2):109-15.

43. Aoyagi Y, Ohashi M, Funahashi R, Otaka Y, Saitoh E. Oropharyngeal Dysphagia and Aspiration Pneumonia Following Coronavirus Disease 2019: A Case Report. Dysphagia [Internet]. 2020 Aug 12;35(4):545-8.

44. Mei X, Zhang Y, Zhu H, Ling Y, Zou Y, Zhang Z, et al. Observations about symptomatic and asymptomatic infections of 494 patients with COVID-19 in Shanghai, China. Am J Infect Control [Internet]. 2020 Sep;48(9):1045-50.

45. Lechien JR, Chiesa-Estomba CM, Cabaraux P, Mat Q, Huet K, Harmegnies B, et al. Features of Mild-to-Moderate COVID-19 Patients With Dysphonia. J Voice [Internet]. 2020 Jun; Available from: https://linkinghub.elsevier.com/retrieve/pii/ S0892199720301831

46. Lechien JR, ChiesaEstomba CM, Place S, Van Laethem Y, Cabaraux P, Mat Q, et al. Clinical and epidemiological characteristics of 1420 European patients with mild-to-moderate coronavirus disease 2019. J Intern Med [Internet]. 2020 Sep 17;288(3):335-44.

47. Munro KJ, Uus K, Almufarrij I, Chaudhuri N, Yioe V. Persistent self-reported changes in hearing and tinnitus in post-hospitalisation COVID-19 cases. Int J Audiol [nternet]. 2020 Jul 31;1-2.

48. Karimi-Galougahi M, Naeini AS, Raad N, Mikaniki $\mathrm{N}$, Ghorbani J. Vertigo and hearing loss during the COVID-19 pandemic - is there an association? Acta Otorhinolaryngol Ital [Internet]. 2020 Jun;1-3.

49. Mustafa MWM. Audiological profile of asymptomatic Covid-19 PCR-positive cases. Am J Otolaryngol [Internet]. 2020 May;41(3):102483.

50. Almufarrij I, Uus K, Munro KJ. Does coronavirus affect the audio-vestibular system? A rapid 
systematic review. Int J Audiol [Internet]. 2020 Jul
2;59(7):487-91. 


\section{Nota do Diretor}

João Marcelo Ramalho Alves ${ }^{1}$

O HOSPITAL UNIVERSITÁRIO GAFFRÉE E GUINLE E SUA HISTÓRIA DE LUTA CONTRA AS DOENÇAS INFECTOCONTAGIOSAS NO BRASIL

Chego às portas de um imponente hospital, desço de minha charrete, chovia fraco, ainda muito cedo, fazia frio, inverno de 1930, e o cheiro de estrume misturava aos esgotos que corriam pelas ruas. A angústia e insegurança tomava conta de todos. Em mãos, uma carta assinada pelo Dr. Carlos Chagas, Diretor do Departamento Nacional de Saúde Pública, ao Dr. Gilberto de Moura Costa, Diretor do Hospital Gaffrée e Guinle, que me encaminhava ao Serviço de Sífilis Visceral. Sou gentilmente encaminhado ao Instituto de Pesquisa, na parte posterior do Hospital. De lá podia ver os transeuntes na avenida dos Trapicheiros. Fico paralisado ao admirar os vitrais da escadaria principal, era uma homenagem a moderna bacteriologia onde identifiquei as ilustres figuras de Louis Pasteur, Robert Koch e Oswaldo Cruz....

Fazia calor, mês de janeiro de 1988, no Rio era um inferno, há meses percebi que minha saúde estava abalada. Tinha diarreia frequentemente. Mesmo comendo de tudo, só emagrecia. Uma febre persistente não me deixava dormir e, rotineiramente, acordava a noite com os lençóis encharcados de suor. Percebi inúmeras manchas em minha pele, e na última semana durante o banho palpava caroços em meu pescoço.

Comentei com um tio brincalhão que trabalhava em uma farmácia na Penha. Por ser temporão, tinha apenas alguns anos a mais que eu. Ele era o irmão mais novo do meu pai. Falei-lhe dos meus sintomas, que sentia cansaço, falta apetite constantemente, como se estivesse gripado.

Lembro de ele ficar preocupado comigo e fazer várias perguntas: com que eu estava saindo, se estava namorando, se usava drogas e se alguém que eu conhecia tinha os mesmos sintomas. Após nossa conversa ele fez algumas ligações telefônicas. Lembro que ele, por algumas vezes falou: - é meu sobrinho. Você tem que me ajudar, parece que ele estar com "aquela doença" ... Logo após desligar, ele me entrega um cartão. onde dentro havia uma carta ao Professor Mário Barreto Correia Lima, gastroenterologista do Hospital Universitário Gaffrée e Guinle...

Toca o telefone às $23 \mathrm{~h}$. Todos em casa exaustos e temerosos. Estamos em maio de 2020. $\mathrm{O}$ pior pesadelo de todos os tempos. O mundo mergulhado em uma pandemia. Aa televisão não passa outra coisa: assistimos noticiários nos telejornais mostrando países ricos na Europa como Itália, França, Espanha, Inglaterra e até Estados Unidos com hospitais lotados e número de mortos não para de crescer.

Há duas semanas, apesar de todos os avisos por jornais, revistas, internet e o WhatsApp invadir nossas vidas com notícias desta pandemia, nunca imaginava que chegaria a nos atingir. Continuava a trabalhar como motorista de Uber, após perder meu emprego em uma construtora, a única forma de trazer algum dinheiro para casa foi virar motorista de aplicativo. Meu carro financiado, e logo agora teria que parar? Continuei trabalhando. Há 10 dias percebi que minha garganta arranhava, tive tosse, febre baixa, semelhante a uma gripe que todo ano tenho. Nada grave. Não me preocupei.

Como voltei a morar com meus pais, acabei contaminando minha mãe.

Ela não teve muita sorte, com a perda do meu emprego não consegui mais pagar o plano de saúde. Ficamos dependendo do SUS. Há dois dias, ela ficou muito cansada e a levamos a UPA da Tijuca. Os médicos rapidamente a diagnosticaram como estando com COVID, e não mais podemos ficar junto com ela.

- Alô! Sim, é o Marcos filho de dona Adelaide... ela está bem?

Os segundos entre minha fala e a resposta foram uma eternidade. Culpa, revolta, nervosismo, arrependimento, insegurança... tudo passou por minha mente!

- Senhor Marcos sua mãe está pior. Estamos ligando para informar que ela será transferida para um Leito de CTI COVID, no Hospital Universitário Gaffrée e Guinle na Rua Mariz e Barros, precisamos que o senhor se dirija a nossa unidade da Tijuca para autorizar a transferência...

Se as paredes tivessem ouvidos, se as portas e janelas pudessem falar, milhares de histórias como essas tiveram como protagonista o Hospital Universitário Gaffrée e Guinle.

São heróis anônimos, incansáveis, abnegados, empáticos e dedicados ao extremo em 
minimizar o sofrimento. Desde março de 2020 enfrentamos o maior de todos os desafios: enfrentar uma doença infectocontagiosa de dimensões jamais imaginadas, superando todas as expectativas, exigindo todas nossas forças e testando todos nossos limites, resistência e resiliência.

Foram 9 meses que mais parecem 9 anos. Descobrimos talentos. Descobrimos seres realmente humanos. Reunimos forças onde não mais havia esperança, criamos pontes, reforçamos laços, e continuamos na luta.

Não sabemos quanto tempo está pandemia ainda irá interferir em nossas vidas, no nosso trabalho, nas nossas famílias, enfim, de uma coisa tenho certeza: o Hospital Universitário Gaffrée e
Guinle estará sempre pronto a enfrentá-la, pois temos guerreiros, temos heróis. Temos fé.

Como Jesus Cristo, Madre Teresa de Calcutá, Irmã Dulce, Confúcio, Gandhi, Buda (Sidarta Gautama), Albert Einstein, Thomas Edison, Louis Pasteur, Nelson Mandela, Martin Luther King, que, cada um a seu modo, dedicaram suas vidas a transformar o mundo em lugar melhor para a humanidade, temos, também aqui, no Hospital Gaffrée e Guinle, nossos heróis anônimos, que arriscam suas vidas literalmente, desde a sua inauguração em 1929, todos os dias, dedicando-se, de corpo e alma, à luta para mitigar o sofrimento alheio, com total empenho em salvar a vida, tanto quando possível, de nossos semelhantes. 


\section{Nota de Agradecimento do Corpo Editorial da Revista Cadernos Brasileiros de Medicina a Fundação de Apoio a Pesquisa, Ensino e Assistência à Escola de Medicina e Cirurgia do Rio de Janeiro e ao Hospital Universitário Gaffrée e Guinle, da Universidade Federal do Estado do Rio de Janeiro - FUNRIO}

Rio de Janeiro, 09 de dezembro de 2020.

O conselho editorial da Revista CBM vem por meio desta nota citar alguns fatos relevantes para expressar nossos sinceros agradecimentos a todo conselho executivo da FUNRIO e os demais apoiadores desta nobre instituição.

Ano de 2020, pandemia!!!!

Dois dos maiores traumas que um ser humano pode sofrer é ver alguém morrer sem poder fazer nada ou ter a própria vida em risco, falamos isso, pois é o que todo profissional de saúde está vivendo nesses tempos ainda incertos.

O que faz cada um de nós seguir e dar novo significado as atividades de nossas vidas? Entre tantas, são os exemplos de superação e força que encontramos em nossos caminhos e o apoio de tantos outros próximos ou distantes.

Escrevemos aqui sobre a FUNRIO neste ano, onde todos foram levados ao limite de suas competências e na busca de cumprir seus objetivos estatutários foi formidável em seu apoio e alcance.

O hospital Universitário Gaffrée e Guinle e a Escola de Medicina e Cirurgia da UNIRIO estavam diante do gigante desafio de se organizarem para o enfrentamento da pandemia e encontraram na FUNRIO o apoio de sempre, com toda sobrecarga institucional e individual que estávamos submetidos, o fato de saber que "estávamos juntos" foi de extrema importância para continuar.

O maior exemplo foi o apoio irrestrito ao HUGG para a construção do setor de atendimento dos pacientes com COVID-19, o que ganhou o nome de Setor Covid do HUGG, sendo inaugurado em abril de 2020 e em funcionamento pleno. O tempo para realização e adequação do setor era muito curto e sem o apoio administrativo e financeiro da FUNRIO e de todos os envolvidos naquele trabalho não teria acontecido.

Ao garantir a assistência no HUGG, garantiu o ensino, à pesquisa e projetos de extensão, objetivo estatutário mais importante da FUNRIO.

FUNRIO, parceira e apoiadora de nossa revista, os nossos mais sinceros agradecimentos. 